\title{
Discovery of novel 1,2,3-triazole derivatives as anticancer agents using QSAR and in silico structural modification
}

\author{
Veda Prachayasittikul 1,2, Ratchanok Pingaew ${ }^{3}$, Nuttapat Anuwongcharoen 1,2, Apilak Worachartcheewan ${ }^{2,4}$, \\ Chanin Nantasenamat ${ }^{2}$, Supaluk Prachayasittikul ${ }^{2 *}$, Somsak Ruchirawat ${ }^{5,6,7}$ and Virapong Prachayasittikul ${ }^{1 *}$
}

*Correspondence: supaluk@ swu.ac.th; virapong.pra@ mahidol.ac.th

${ }^{1}$ Department of Clinical Microbiology and Applied Technology, Faculty of Medical Technology, Mahidol University,

Bangkok 10700, Thailand ${ }^{2}$ Center of Data Mining and Biomedical Informatics, Faculty of Medical Technology, Mahidol University, Bangkok 10700, Thailand

Full list of author information is available at the end of the article

\begin{abstract}
Considerable attention has been given on the search for novel anticancer drugs with respect to the disease sequelae on human health and well-being. Triazole is considered to be an attractive scaffold possessing diverse biological activities. Structural modification on the privileged structures is noted as an effective strategy towards successful design and development of novel drugs. The quantitative structure-activity relationships (QSAR) is well-known as a powerful computational tool to facilitate the discovery of potential compounds. In this study, a series of thirty-two 1,2,3-triazole derivatives (1-32) together with their experimentally measured cytotoxic activities against four cancer cell lines i.e., HuCCA-1, HepG2, A549 and MOLT-3 were used for QSAR analysis. Four QSAR models were successfully constructed with acceptable predictive performance affording $R_{\mathrm{CV}}$ ranging from 0.5958 to 0.8957 and $\mathrm{RMSE}_{\mathrm{CV}}$ ranging from 0.2070 to 0.4526 . An additional set of 64 structurally modified triazole compounds $(\mathbf{1 A}-\mathbf{1} \mathbf{R}$,

2A-2R, 7A-7R and $\mathbf{8 A}-\mathbf{8 R}$ ) were constructed in silico and their predicted cytotoxic activities were obtained using the constructed QSAR models. The study suggested crucial moieties and certain properties essential for potent anticancer activity and highlighted a series of promising compounds $(\mathbf{2 1}, \mathbf{2 8}, \mathbf{3 2}, \mathbf{1 P}, \mathbf{8 G}, \mathbf{8 N}$ and $\mathbf{8 Q})$ for further development as novel triazole-based anticancer agents.
\end{abstract}

Keywords: Triazoles, Anticancer activity, Drug design, Computational chemistry, QSAR, Structural modification

\section{Background}

Great attention has been given towards prevention and treatment of cancers with respect to the impact of disease sequelae on long term well-being of individuals (Vos et al. 2012). Cancers have been reported as one of the Global Burden of Diseases (World Health Organization 2008) and are estimated to be one of main causes of death in the coming decades (Mathers and Loncar 2006; Soerjomataram et al. 2012). Therefore, the search for novel anticancer agents has become one of prime interests in drug discovery and development.

1,2,3-Triazoles are nitrogen heterocycles capable of forming hydrogen bonds which improves their solubility and ability to interact with biomolecular targets (Vatmurge et al. 2008). The 1,2,3-triazoles are highly stable to metabolic degradation as compared to

(c) 2015 Prachayasittikul et al. This article is distributed under the terms of the Creative Commons Attribution 4.0 International License (http://creativecommons.org/licenses/by/4.0/), which permits unrestricted use, distribution, and reproduction in any medium, provided you give appropriate credit to the original author(s) and the source, provide a link to the Creative Commons license, and indicate if changes were made. 
other compounds containing three adjacent nitrogen (N) atoms (Vatmurge et al. 2008). The triazoles have been used for broad therapeutic applications due to their diverse biological activities (Agalave et al. 2011) i.e., antimicrobial (Shivarama Holla et al. 1998; Prasad et al. 2009; Turan-Zitouni et al. 2005), antiviral (Masuda et al. 1975), antiinflammatory (Almasirad et al. 2004), analgesic (Almasirad et al. 2004), anticancer (Holla et al. 2002; Shivarama Holla et al. 2003; Pingaew et al. 2014a, b), antifungal (Manclús et al. 2008) and anticonvulsant (Amir and Shikha 2004) activities. In this regards, these privileged scaffolds have drawn considerable attention in the field of medicinal chemistry (Kumar and Kavitha 2013).

The computational approaches are widely known for their effectiveness in facilitating drug design and discovery (Kaul 1998). Quantitative structure-activity relationships (QSAR) is an in silico method for correlating structures of the compounds with their biological activities (Nantasenamat et al. 2009, 2010). QSAR can significantly reduce cost and time of drug discovery pipeline (Perkins et al. 2003) since the method provides beneficial knowledge for rational drug design such as crucial properties or moieties required for potent activities and pharmacokinetic information (Hansch et al. 2004). The QSAR models have been successfully constructed for understanding structure-activity relationships (SAR) of a wide range of bioactive compounds and diverse biological activities (Prachayasittikul et al. 2014; Nantasenamat et al. 2014; Worachartcheewan et al. 2012, 2013, 2014a, b, c).

Structural modification is extensively used to obtain potential lead compounds with improved potency and pharmacokinetic properties as well as reduced toxicities (Hughes et al. 2011; Anderson 2003; Prachayasittikul et al. 2014). The lack of structural diversity is one of current problems in the field of drug discovery which leads the growing awareness on expansion of chemical space (Barker et al. 2013; Dandapani and Marcaurelle 2010). The modification on privileged scaffolds is one of efficacious strategies to increase structural diversity thereby potentially addresses current issue. In addition, structural modification on the triazole pharmacophore has been noted as an efficient concept in the search for novel triazole drugs (Chrysina et al. 2009; Pingaew et al. 2014a, b).

Recently, a set of novel disubstituted 1,2,3-triazole derivatives (1-32, Fig. 1) has been reported as cytotoxic agents against four cancer cell lines i.e., HuCCA-1, HepG2, A549 and MOLT-3 by our research group (Pingaew et al. 2014a, b). Molecular docking of the tetrahydroisoquinoline-triazole derivatives 16-32 revealed that an aldo-keto reductase 1C3 (AKR1C3) has been identified to be a plausible target responsible for their anticancer activity (Pingaew et al. 2014a). In addition, the 1,2,3-triazoles (2-7, 12-13 and 15) were shown to be aromatase inhibitors (Pingaew et al. 2015). The 1,2,3-triazole ring can be synthesized using copper catalyzed azide-alkyne cycloaddition (CuAAC), known as the Click reaction. The analytical data of the reported compounds is provided in supplementary data. These triazoles were substituted by phenylsulfonyl (opened and closed chain analogs containing substituent $\mathrm{R}^{1}$ ) at position 1 ; and by $\mathrm{R}$ group as phenyl and phenyl(naphthalenyl/coumaryl)oxymethyl at position 4 . General core structures of compounds 1-32 are summarized as opened chain (1-15) and closed chain sulfonamides (16-32) as shown in Fig. 2. Triazole and sulfonyl moieties of compounds 1-32 are substituted at 1,4-positions (para-) of the phenyl ring. For simplification, compounds 1-32 will be denoted as para-trizoles. In this study, the QSAR was employed as a tool 


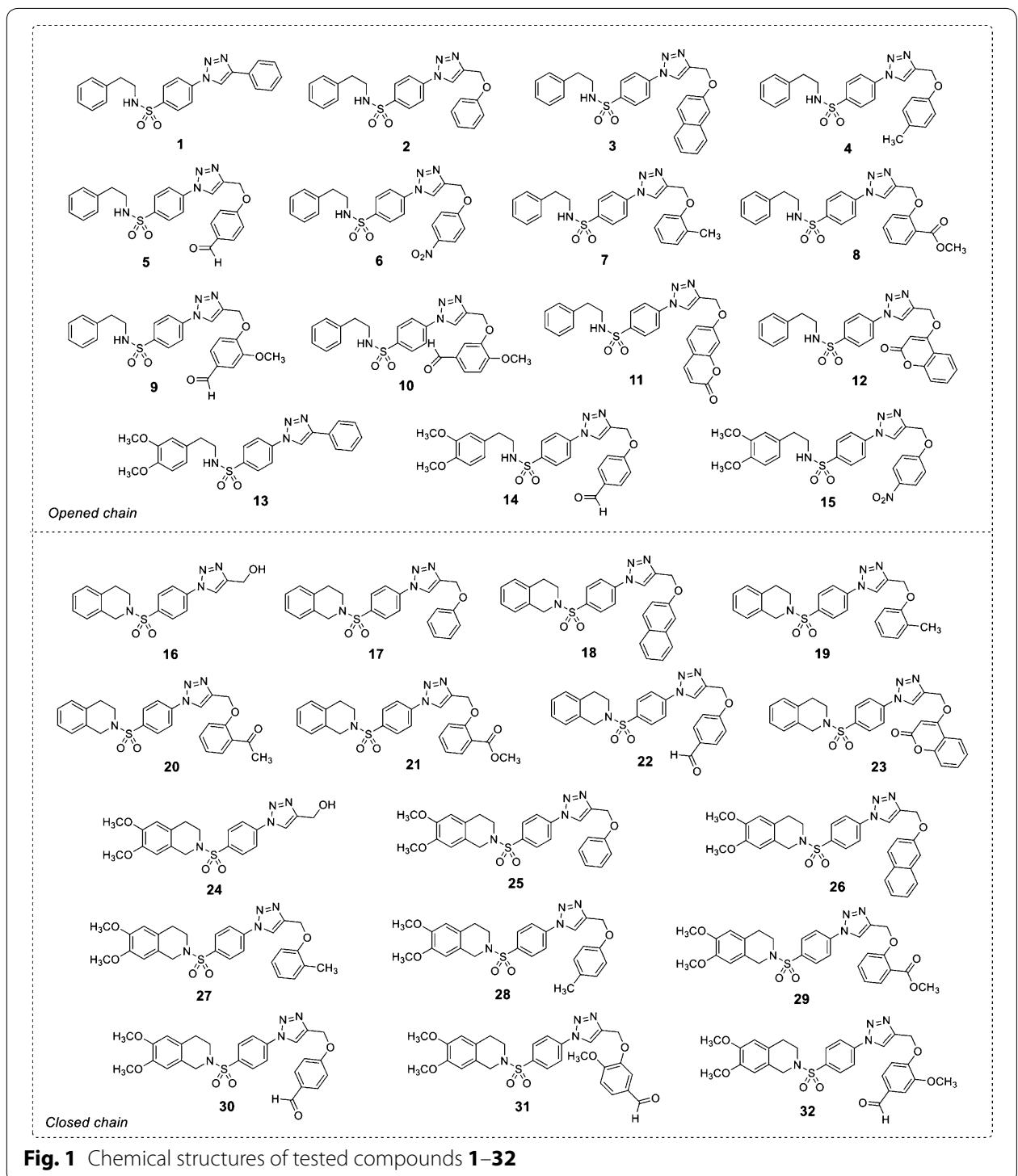

for understanding SAR of these 1,2,3-triazole derivatives. Four QSAR models were constructed using the chemical structure of the 32 tested compounds (1-32) along with their experimental cytotoxic activity. Furthermore, the application of constructed QSAR models were extended for the prediction of cytotoxic activity of an additional set of 64 structurally modified compounds (1A-1R, 2A-2R, 7A-7R and $\mathbf{8 A - 8 R}$, Figs. 3, 4, 5, 6) constructed in silico. Such structural modification of the compounds was rationally designed based on hydrophobic, electronic and steric effects as previously described by Topliss $(1972,1977)$. Therefore, the structurally modified compounds were obtained on the basis of changing groups on core structure (opened or closed chain), adding functional groups and altering the substitution positions of triazole and sulfonyl moieties on the phenyl ring (i.e., para- and meta-) to give para- and meta-triazoles, respectively (Fig. 7). A comprehensive analysis revealed important properties, crucial moieties and rigid analogs necessary for potent cytotoxic activity of the triazole compounds which 


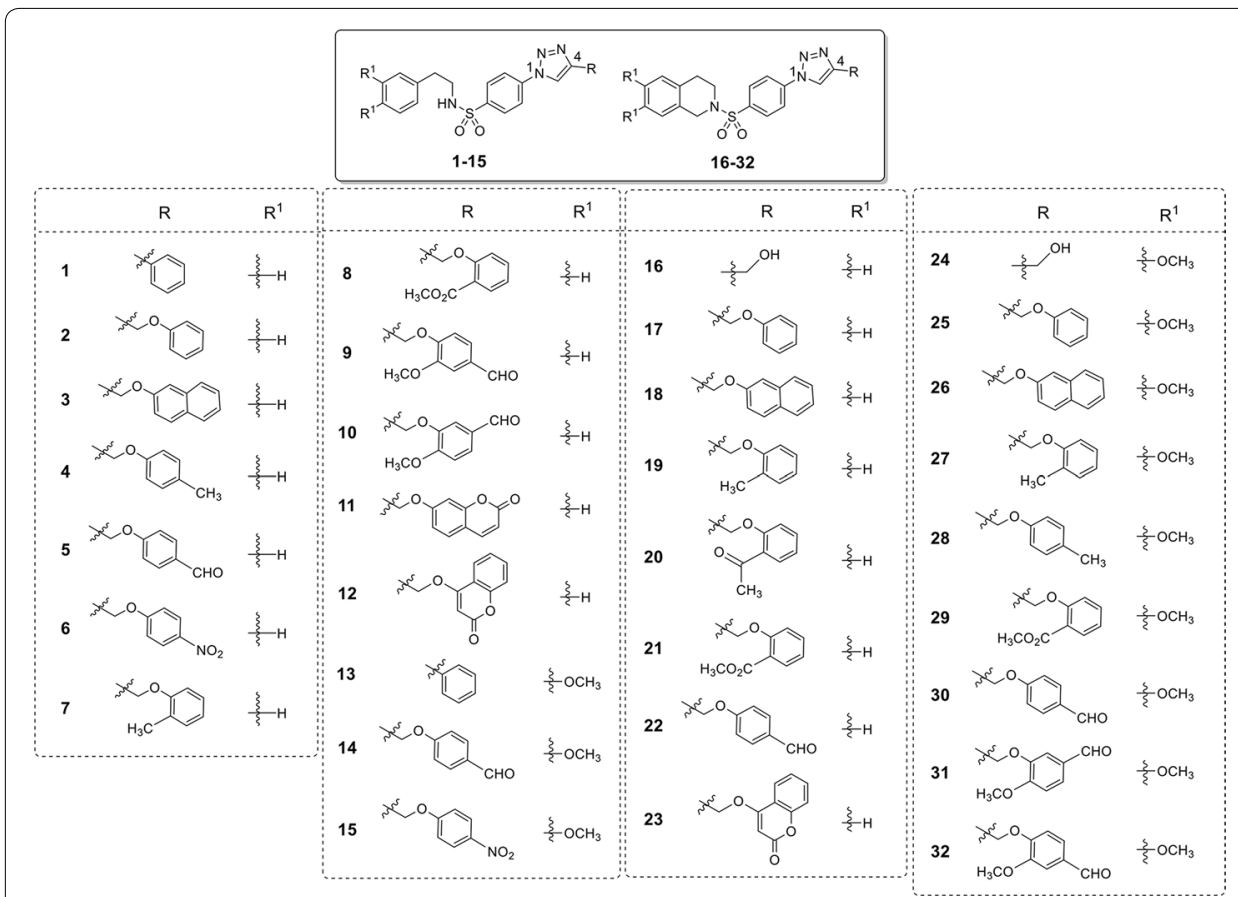

Fig. 2 The substitutions on opened (1-15) and closed (16-32) chain core structures of 1,2,3-triazole

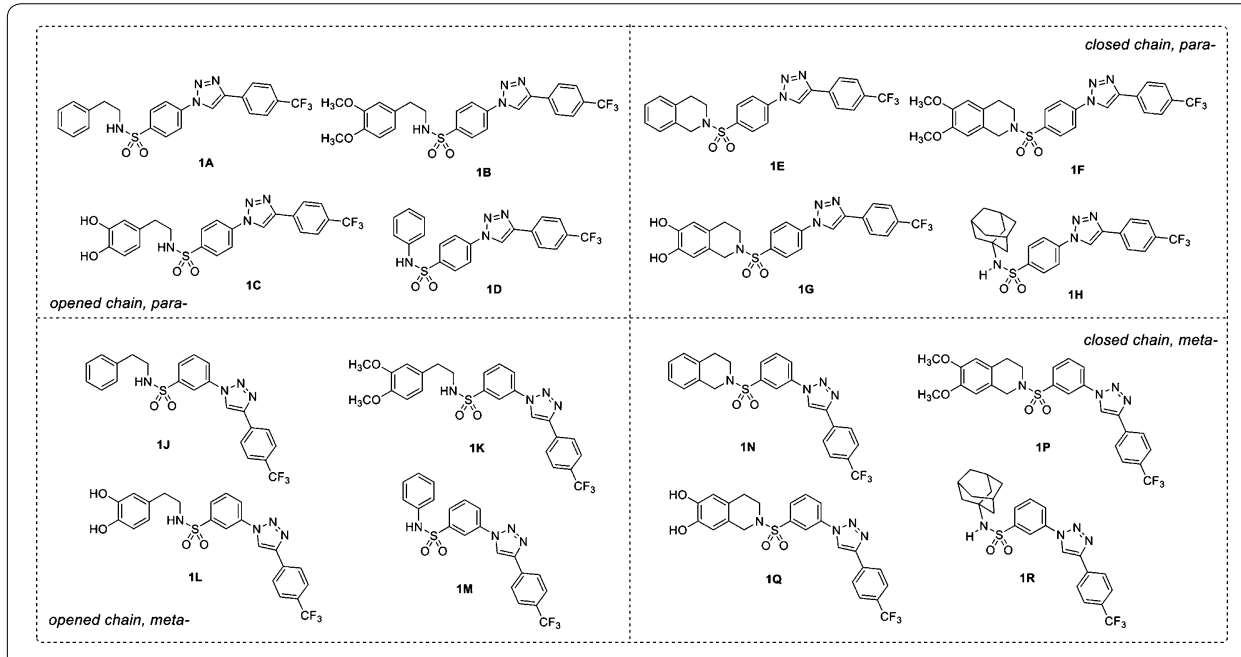

Fig. 3 Chemical structures of modified compound series $\mathbf{1}(\mathbf{1 A}-\mathbf{1 R})$

would be of great benefit for guiding the design, screening and development of novel triazole anticancer drugs.

\section{Results and discussion}

\section{Data sets}

The data for QSAR analysis was obtained from the literature reported by our research group (Pingaew et al. 2014a, b). Analytical data of the reported compounds is provided in Additional file 1 . The experimental cytotoxic activities $\left(\mathrm{IC}_{50}\right)$ of the tested 


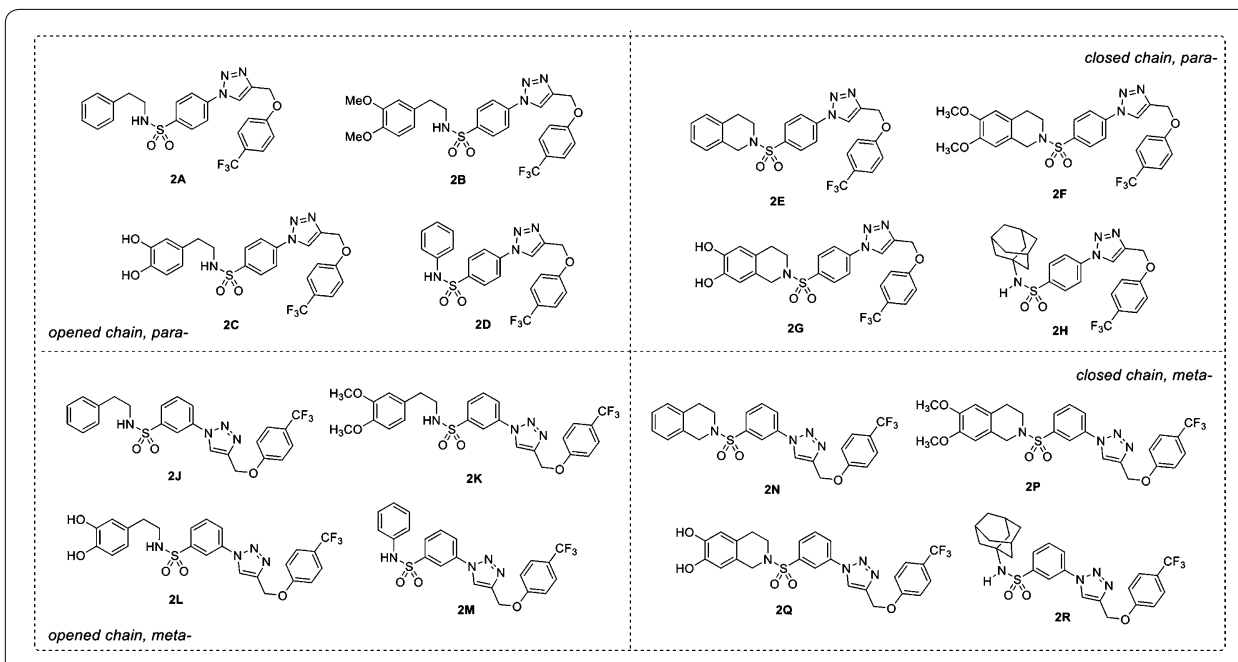

Fig. 4 Chemical structures of modified compound series $\mathbf{2}(\mathbf{2 A}-\mathbf{2 R})$

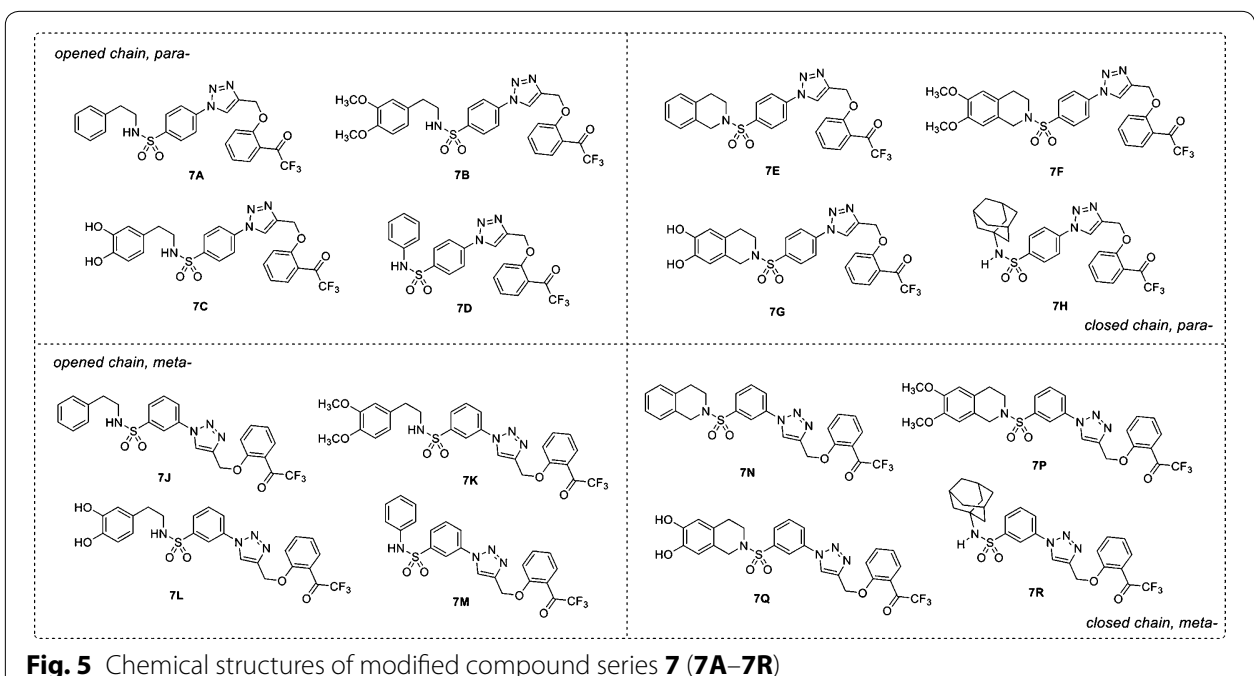

compounds (1-32) are shown in Table 1. The compounds (1-32) were classified by their $\mathrm{IC}_{50}$ values into four classes i.e., highly active $\left(\mathrm{IC}_{50}<1 \mu \mathrm{M}\right)$, moderately active $\left(1 \mu \mathrm{M}<\mathrm{IC}_{50}<10 \mu \mathrm{M}\right)$, weakly active $\left(\mathrm{IC}_{50}>10 \mu \mathrm{M}\right)$ (Pérez-Sacau et al. 2007) and inactive $\left(\mathrm{IC}_{50}>50 \mu \mathrm{g} / \mathrm{mL}\right.$ ) (Prachayasittikul et al. 2014). All inactive compounds were excluded from the QSAR analysis. Four QSAR models were separately constructed based on experimental testing against four cancer cell lines.

\section{Obtaining informative descriptor values}

Chemical structures of 32 triazole derivatives (1-32) were drawn, geometrically optimized, and calculated to obtain a set of descriptor values containing 13 quantum chemical descriptors and 3,224 molecular descriptors. The feature selection using correlation-based followed by stepwise multiple linear regression (MLR) methods was performed to select a set of significant informative descriptors of each cell line in which their definitions and values are shown in Table 2 and Additional file 2, respectively. 

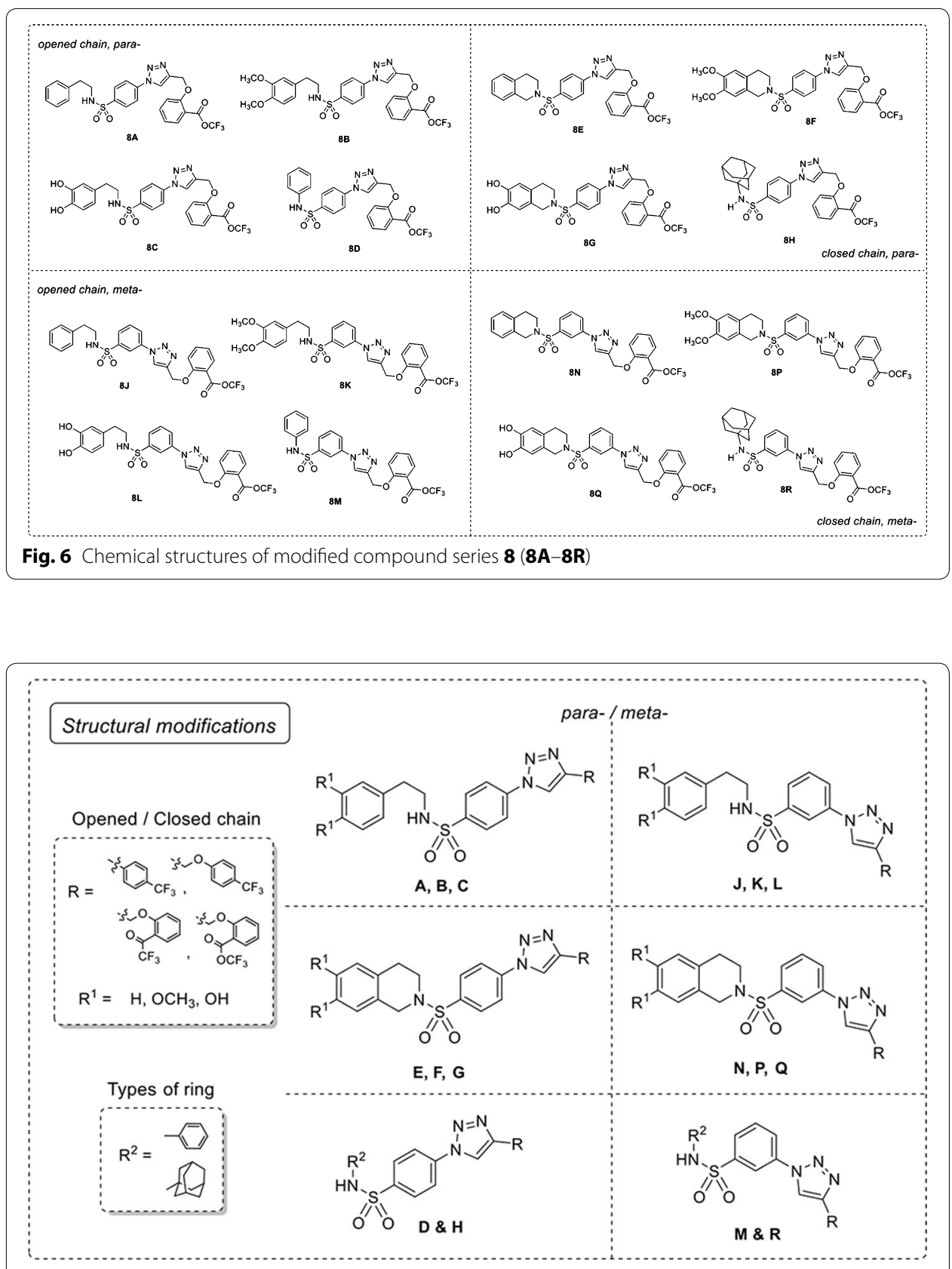

Fig. 7 Modification on 1,2,3-triazole scaffold series 1, 2, 7 and $\mathbf{8}$

\section{QSAR analysis}

The multiple linear regression (MLR) is one of the most popularly used machine learning algorithms for understanding SAR and it has been successfully employed for predicting bioactivities of diverse classes of compounds (Prachayasittikul et al. 2014; Worachartcheewan et al. 2012, 2013, 2014b, c). Regarding cytotoxic activity against four cancer cell lines, the data were separated into four data sets for QSAR analysis. Four QSAR models were successfully constructed by MLR method using a set of selected informative descriptor values and experimental cytotoxic activities $\left(\mathrm{pIC}_{50}\right)$. The QSAR models and 
Table 1 Experimental cytotoxic activity of triazoles 1-32 against four cancer cell lines

\begin{tabular}{|c|c|c|c|c|}
\hline \multirow[t]{2}{*}{ Compound } & \multicolumn{4}{|l|}{$\mathrm{IC}_{50}(\mu \mathrm{M})$} \\
\hline & HuCCA-1 & HepG2 & A549 & MOLT-3 \\
\hline 1 & $8.65 \pm 1.70^{b}$ & $9.07 \pm 1.15^{b}$ & $34.54 \pm 0.89^{c}$ & Inactive $^{d}$ \\
\hline 2 & Inactive $^{d}$ & $57.54 \pm 8.66^{c}$ & Inactive ${ }^{d}$ & Inactive $^{d}$ \\
\hline 3 & Inactive ${ }^{d}$ & $28.21 \pm 2.89^{c}$ & Inactive $^{d}$ & $74.23 \pm 5.08^{c}$ \\
\hline 4 & Inactive $^{d}$ & $81.75 \pm 2.89^{c}$ & Inactive $^{d}$ & Inactive ${ }^{d}$ \\
\hline 5 & $87.89 \pm 0.92^{c}$ & $100.54 \pm 2.12^{c}$ & Inactive $^{d}$ & $32.02 \pm 0.76^{c}$ \\
\hline 6 & Inactive ${ }^{d}$ & Inactive $^{d}$ & Inactive ${ }^{d}$ & $61.42 \pm 1.01^{c}$ \\
\hline 7 & Inactive $^{d}$ & $41.62 \pm 1.15^{c}$ & Inactive $^{d}$ & $34.24 \pm 3.11^{c}$ \\
\hline 8 & Inactive $^{d}$ & $49.40 \pm 4.04^{c}$ & Inactive $^{d}$ & $8.81 \pm 0.42^{b}$ \\
\hline 9 & Inactive $^{d}$ & $57.52 \pm 6.51^{c}$ & $79.18 \pm 14.15^{c}$ & $9.22 \pm 0.48^{b}$ \\
\hline 10 & Inactive $^{d}$ & $34.51 \pm 4.36^{c}$ & $39.04 \pm 0.37^{c}$ & $10.33 \pm 0.08^{c}$ \\
\hline 11 & $16.12 \pm 0.71^{c}$ & $12.44 \pm 1.71^{c}$ & $19.60 \pm 2.33^{c}$ & $88.97 \pm 3.42^{c}$ \\
\hline 12 & Inactive ${ }^{d}$ & Inactive $^{d}$ & Inactive $^{d}$ & $10.65 \pm 0.48^{c}$ \\
\hline 13 & Inactive $^{d}$ & $23.89 \pm 3.00^{c}$ & $18.19 \pm 0.35^{c}$ & $60.99 \pm 6.66^{c}$ \\
\hline 14 & Inactive $^{d}$ & Inactive ${ }^{d}$ & $28.03 \pm 1.63^{c}$ & $17.43 \pm 0.41^{c}$ \\
\hline 15 & Inactive $^{d}$ & Inactive $^{d}$ & Inactive $^{d}$ & $10.10 \pm 0.27^{c}$ \\
\hline 16 & $51.35 \pm 5.66^{c}$ & Inactive $^{d}$ & Inactive $^{d}$ & Inactive $^{d}$ \\
\hline 17 & Inactive $^{d}$ & $6.50 \pm 0.14^{b}$ & Inactive $^{d}$ & Inactive $^{d}$ \\
\hline 18 & Inactive ${ }^{d}$ & $60.48 \pm 14.14^{c}$ & Inactive ${ }^{d}$ & Inactive ${ }^{d}$ \\
\hline 19 & Inactive $^{d}$ & Inactive $^{d}$ & $66.30 \pm 0.70^{c}$ & Inactive $^{d}$ \\
\hline 20 & $30.16 \pm 4.07^{c}$ & $19.12 \pm 3.06^{c}$ & $14.90 \pm 1.02^{c}$ & $21.86 \pm 3.67^{c}$ \\
\hline 21 & $0.63 \pm 0.04^{\mathrm{a}, \mathrm{e}}$ & $12.36 \pm 1.97^{c}$ & $0.57 \pm 0.02^{\mathrm{a}, \mathrm{e}}$ & $18.63 \pm 1.62^{c}$ \\
\hline 22 & Inactive $^{d}$ & $5.27 \pm 0.71^{b}$ & $59.07 \pm 11.31^{c}$ & Inactive ${ }^{d}$ \\
\hline 23 & $24.80 \pm 2.19^{c}$ & Inactive ${ }^{d}$ & $25.29 \pm 10.78^{c}$ & $80.78 \pm 10.23^{c}$ \\
\hline 24 & $72.0 \pm 10.54^{c}$ & $31.79 \pm 2.89^{c}$ & $41.04 \pm 9.40^{c}$ & Inactive $e^{d}$ \\
\hline 25 & Inactive $^{d}$ & $2.57 \pm 0.99^{b}$ & Inactive $^{d}$ & Inactive $^{d}$ \\
\hline 26 & Inactive $^{d}$ & $1.26 \pm 0.42^{b}$ & Inactive $^{d}$ & $36.35 \pm 1.36^{c}$ \\
\hline 27 & $39.71 \pm 1.48^{c}$ & $1.48 \pm 0.61^{b}$ & $27.21 \pm 1.77^{c}$ & Inactive ${ }^{d}$ \\
\hline 28 & inactive $^{d}$ & $0.56 \pm 0.01^{a, e}$ & Inactive $^{d}$ & Inactive $^{d}$ \\
\hline 29 & $4.79 \pm 0.28^{b}$ & $3.37 \pm 0.96^{b}$ & $8.43 \pm 2.79^{b}$ & $11.74 \pm 4.97^{c}$ \\
\hline 30 & $31.09 \pm 8.91^{c}$ & $12.49 \pm 2.47^{c}$ & $31.84 \pm 8.13^{c}$ & $34.12 \pm 0.97^{c}$ \\
\hline 31 & $76.15 \pm 1.77^{c}$ & $41.36 \pm 2.89^{c}$ & $31.91 \pm 9.76^{c}$ & $5.82 \pm 0.85^{b}$ \\
\hline 32 & $39.98 \pm 4.03^{c}$ & Inactive $^{d}$ & Inactive $^{d}$ & $5.50 \pm 0.61^{b, e}$ \\
\hline Etoposide ${ }^{f}$ & -9 & $30.16 \pm 0.50$ & -9 & $0.051 \pm 0.002$ \\
\hline Doxorubixin $^{f}$ & $0.83 \pm 0.07$ & $0.79 \pm 0.08$ & $0.44 \pm 0.01$ & -9 \\
\hline
\end{tabular}

The compounds (1-32) were classified by their $I C_{50}$ values into four classes i.e., highly active $\left(I_{50}<1 \mu \mathrm{M}\right)$, moderately active $\left(1 \mu \mathrm{M}<\mathrm{IC}_{50}<10 \mu \mathrm{M}\right)$, weakly active $\left(\mathrm{IC}_{50}>10 \mu \mathrm{M}\right)$ (Pérez-Sacau et al. 2007) and inactive $\left(\mathrm{IC}_{50}>50 \mu \mathrm{g} / \mathrm{mL}\right)$ (Prachayasittikul et al. 2014). All inactive compounds were excluded from the QSAR analysis. Four QSAR models were separately constructed based on experimental testing against four cancer cell lines

a Highly active compound

${ }^{b}$ Moderately active compound

c Weakly active compound

d Inactive compound

e The most potent compound against each cell line

${ }^{f}$ Reference drugs

g Not tested

their predictive performance parameters are summarized in Table 3. Acceptable predictive performances were obtained from all constructed QSAR models with $R_{c v}$ and $\mathrm{RMSE}_{\mathrm{cv}}$ values ranging from 0.5958 to 0.8957 and $0.2070-0.4526$, respectively. The 
Table 2 Definition of descriptors using for development of QSAR models

\begin{tabular}{|c|c|c|}
\hline Descriptor & Type & Definition \\
\hline $\mathrm{R} 5 \mathrm{e}+$ & GETAWAY descriptors & $\begin{array}{l}\text { R maximal autocorrelation of lag 5/weighted by Sanderson elec- } \\
\text { tronegativity }\end{array}$ \\
\hline nArCOOR & Functional group counts & Number of esters (aromatic) \\
\hline RDF105m & RDF descriptors & Radial Distribution Function-105/weighted by mass \\
\hline MATS7m & 2D autocorrelations & Moran autocorrelation of lag 7 weighted by mass \\
\hline MATS8V & 2D autocorrelations & Moran autocorrelation of lag 8 weighted by van der Waals volume \\
\hline Lop & lopping centric index & Topological indices \\
\hline R7m & GETAWAY descriptors & $\mathrm{R}$ autocorrelation of lag 7/weighted by atomic masses \\
\hline
\end{tabular}

Table 3 Summary of QSAR models and their predictive performances against four cancer cell line

\begin{tabular}{lllllll}
\hline Cell line & Equation & $\mathbf{N}$ & $\boldsymbol{R}_{\mathbf{T r}}$ & $\mathbf{R M S E}_{\mathbf{T r}}$ & $\boldsymbol{R}_{\mathbf{C v}}$ & $\mathbf{R M S E}_{\mathbf{C v}}$ \\
\hline HuCCA-1 & $p / C_{50}=-84.0157($ R5e +$)+1.0288($ nArCOOR $)+0.8738$ & 13 & 0.9597 & 0.1603 & 0.8957 & 0.2562 \\
HepG2 & $p / C_{50}=0.0784($ RDF105 m) $+5.1878($ MATS7 m $)-1.7524$ & 24 & 0.7537 & 0.4006 & 0.6724 & 0.4526 \\
A549 & $p / C_{50}=1.5979($ MATS8v $)+0.9251($ nARCOOR $)-1.7829$ & 16 & 0.8673 & 0.2390 & 0.5958 & 0.4211 \\
MOLT-3 & $p / C_{50}=1.0649($ Lop $)+10.3977(R 7 m)-5.6832$ & 20 & 0.8936 & 0.1714 & 0.8430 & 0.2070
\end{tabular}

$\mathrm{plC}_{50}$ is the concentration of compound required for $50 \%$ inhibition of cell growth

$N$ number of data set, $R_{T r}$ correlation coefficient of the training set, $R M S E_{T r}$ root mean square error of the training set, $R_{C V}$ correlation coefficient of leave-one-out cross validation (LOO-CV) of the testing set, $R M S E_{C V}$ root mean square error LOO-CV of the testing set

highest performance was achieved from the HuCCA-1 model showing $R_{c v}=0.8957$ and $\mathrm{RMSE}_{\mathrm{cv}}=0.2562$ whereas the lowest performance was observed for A549 model $\left(R_{c v}=0.5958, \mathrm{RMSE}_{\mathrm{cv}}=0.4211\right)$. The experimental and predicted cytotoxic activities against four cancer cell lines $\left(\mathrm{pIC}_{50}\right)$ are shown in Table 4 and Fig. 8.

\section{Prediction of cytotoxic activities of virtually modified compounds}

In order to investigate the effects of structural modification on the core structures of triazoles as opened chain (1-15) and closed chain (16-32), a series of structural modified compounds (1A-1R, $\mathbf{2 A}-\mathbf{2 R}, \mathbf{7 A}-\mathbf{7 R}$ and $\mathbf{8 A}-\mathbf{8 R})$ were virtually constructed based on the changing substituents as shown in Fig. 7.

The modified compounds were drawn, geometrically optimized and calculated to obtain distinct sets of important descriptor values of each QSAR models (Additional file 2) for subsequently calculation of their predicted activities. The structurally modified compounds were categorized by their predicted cytotoxic activities as highly active $\left(\mathrm{pIC}_{50}>0\right)$, moderately active $\left(-1<\mathrm{pIC}_{50}<0\right)$ and weakly to inactive $\left(\mathrm{pIC}_{50}<-1\right)$ (Prachayasittikul et al. 2014). The predicted cytotoxic activity ( $\mathrm{pIC}_{50}$ ) of modified compound series are shown in Additional file 3.

\section{Understanding structure-activity relationships}

Comprehensive consideration of experimental activities of the tested compounds (1-32) and predicted cytotoxic activities of modified compounds $(\mathbf{1 A}-\mathbf{1 R}, \mathbf{2 A}-\mathbf{2 R}, \mathbf{7 A}-\mathbf{7 R}$ and $\mathbf{8 A - 8 R}$, Figs. 3, 4, 5, 6) against four cancer cell lines along with their descriptor values were performed to understand the SAR. The effects of structural modifications by 
Table 4 Experimental and predicted cytotoxic activities $\left(\mathrm{plC}_{50}\right)$ of compounds 1-32 against cancer cell lines

\begin{tabular}{|c|c|c|c|c|c|c|c|c|}
\hline \multirow[t]{2}{*}{ Compound } & \multicolumn{2}{|c|}{ HuCCA-1 } & \multicolumn{2}{|l|}{ HepG2 } & \multicolumn{2}{|l|}{ A549 } & \multicolumn{2}{|l|}{ MOLT-3 } \\
\hline & Exp. & Pred. & Exp. & Pred. & Exp. & Pred. & Exp. & Pred. \\
\hline 1 & -0.937 & -1.004 & -0.958 & -1.571 & -1.538 & -1.345 & $--^{\mathrm{a}}$ & $-^{\mathrm{a}}$ \\
\hline 2 & $-^{\mathrm{a}}$ & $-^{\mathrm{a}}$ & -1.760 & -1.640 & $-^{\mathrm{a}}$ & $-^{\mathrm{a}}$ & $--^{\mathrm{a}}$ & $-^{\mathrm{a}}$ \\
\hline 3 & $-{ }^{\mathrm{a}}$ & $--^{\mathrm{a}}$ & -1.450 & -1.543 & $-{ }^{\mathrm{a}}$ & $--^{a}$ & -1.871 & -1.797 \\
\hline 4 & $-^{a}$ & $-^{\mathrm{a}}$ & -1.912 & -1.514 & $-^{\mathrm{a}}$ & $--^{a}$ & $-^{\mathrm{a}}$ & $-^{\mathrm{a}}$ \\
\hline 5 & -1.944 & -1.790 & -2.002 & -1.835 & $-^{\mathrm{a}}$ & $--^{a}$ & -1.505 & -1.588 \\
\hline 6 & $-^{a}$ & $-^{\mathrm{a}}$ & $-^{a}$ & $-^{\mathrm{a}}$ & $--^{a}$ & $--^{a}$ & -1.788 & -1.548 \\
\hline 7 & $-^{a}$ & $-^{\mathrm{a}}$ & -1.619 & -1.624 & $--^{a}$ & $--^{a}$ & -1.535 & -1.513 \\
\hline 8 & $--^{a}$ & $-^{\mathrm{a}}$ & -1.694 & -1.711 & $-^{\mathrm{a}}$ & $--^{a}$ & -0.945 & -0.833 \\
\hline 9 & $-^{a}$ & $-^{\mathrm{a}}$ & -1.760 & -1.426 & -1.899 & -1.760 & -0.965 & -1.306 \\
\hline 10 & $--^{a}$ & $-^{\mathrm{a}}$ & -1.538 & -1.524 & -1.592 & -1.790 & -1.014 & -1.074 \\
\hline 11 & -1.207 & -1.420 & -1.095 & -1.739 & -1.292 & -1.544 & -1.949 & -1.785 \\
\hline 12 & $-^{\mathrm{a}}$ & $-^{\mathrm{a}}$ & $-^{\mathrm{a}}$ & $-^{\mathrm{a}}$ & $-^{\mathrm{a}}$ & $-^{\mathrm{a}}$ & -1.027 & -1.497 \\
\hline 13 & $-^{a}$ & $-^{\mathrm{a}}$ & -1.378 & -0.589 & -1.260 & -1.231 & -1.785 & -1.775 \\
\hline 14 & $--^{a}$ & $-^{\mathrm{a}}$ & $--^{a}$ & $-^{\mathrm{a}}$ & -1.448 & -1.540 & -1.241 & -1.319 \\
\hline 15 & $-{ }^{a}$ & $-^{\mathrm{a}}$ & $-{ }^{\mathrm{a}}$ & $--^{a}$ & $-^{\mathrm{a}}$ & $-^{\mathrm{a}}$ & -1.004 & -1.238 \\
\hline 16 & -1.711 & -1.454 & $-{ }^{a}$ & $-^{\mathrm{a}}$ & $-^{a}$ & $--^{a}$ & $-^{\mathrm{a}}$ & $-^{\mathrm{a}}$ \\
\hline 17 & $-^{a}$ & $-^{\mathrm{a}}$ & -0.813 & -1.241 & $-^{\mathrm{a}}$ & $-^{a}$ & $--^{\mathrm{a}}$ & $-^{\mathrm{a}}$ \\
\hline 18 & $-^{a}$ & $-^{\mathrm{a}}$ & -1.782 & -1.112 & $-^{\mathrm{a}}$ & $--^{a}$ & $--^{a}$ & $--^{a}$ \\
\hline 19 & $-^{a}$ & $-^{\mathrm{a}}$ & $-^{\mathrm{a}}$ & $-^{\mathrm{a}}$ & -1.822 & -1.498 & $-^{\mathrm{a}}$ & $-^{\mathrm{a}}$ \\
\hline 20 & -1.479 & -1.665 & -1.281 & -1.090 & -1.173 & -1.415 & -1.340 & -1.216 \\
\hline 21 & 0.201 & -0.306 & -1.092 & -0.858 & 0.244 & -0.857 & -1.270 & -1.423 \\
\hline 22 & $-^{a}$ & $-^{\mathrm{a}}$ & -0.722 & -1.259 & -1.771 & -1.635 & $-^{\mathrm{a}}$ & $-^{\mathrm{a}}$ \\
\hline 23 & -1.394 & -1.051 & $-^{\mathrm{a}}$ & $-^{\mathrm{a}}$ & -1.403 & -1.252 & -1.907 & -1.640 \\
\hline 24 & -1.857 & -2.031 & -1.502 & -1.431 & -1.613 & -1.524 & $--^{\mathrm{a}}$ & $-^{\mathrm{a}}$ \\
\hline 25 & $-^{\mathrm{a}}$ & $-^{\mathrm{a}}$ & -0.410 & -0.589 & $-^{\mathrm{a}}$ & $-^{a}$ & $-^{\mathrm{a}}$ & $-^{\mathrm{a}}$ \\
\hline 26 & $--^{\mathrm{a}}$ & $-^{\mathrm{a}}$ & -0.100 & -0.859 & $-{ }^{a}$ & $-{ }^{a}$ & -1.561 & -1.604 \\
\hline 27 & -1.599 & -1.652 & -0.170 & -0.456 & -1.435 & -1.449 & $-^{\mathrm{a}}$ & $-^{\mathrm{a}}$ \\
\hline 28 & $-^{\mathrm{a}}$ & $-^{\mathrm{a}}$ & 0.252 & -0.449 & $-^{\mathrm{a}}$ & $-^{a}$ & $-^{\mathrm{a}}$ & $-^{\mathrm{a}}$ \\
\hline 29 & -0.680 & -0.173 & -0.528 & -0.590 & -0.926 & 0.176 & -1.070 & -0.609 \\
\hline 30 & -1.493 & -1.570 & -1.097 & -0.866 & -1.503 & -1.573 & -1.533 & -1.412 \\
\hline 31 & -1.882 & -1.802 & -1.617 & -0.653 & -1.504 & -1.664 & -0.765 & -0.843 \\
\hline 32 & -1.602 & -1.652 & $-^{\mathrm{a}}$ & $-^{\mathrm{a}}$ & $-^{\mathrm{a}}$ & $-^{\mathrm{a}}$ & -0.740 & -0.749 \\
\hline
\end{tabular}

Exp. experimental activity, Pred. predicted activity

a Compounds determined to be experimentally inactive and were excluded from QSAR analysis

changing substituents $\mathrm{R}$ and $\mathrm{R}^{1}$ (Figs. 2, 7) were observed and summarized in Additional file 4. The effects of substitutions on meta- and para-trizoles were compared based on the modified compound series obtaining the best improved activity against particular cancer cell line (Additional file 5).

HuCCA-1 cell line

$$
p I C_{50}=-84.0157(R 5 e+)+1.0288(n A r C O O R)+0.8738
$$




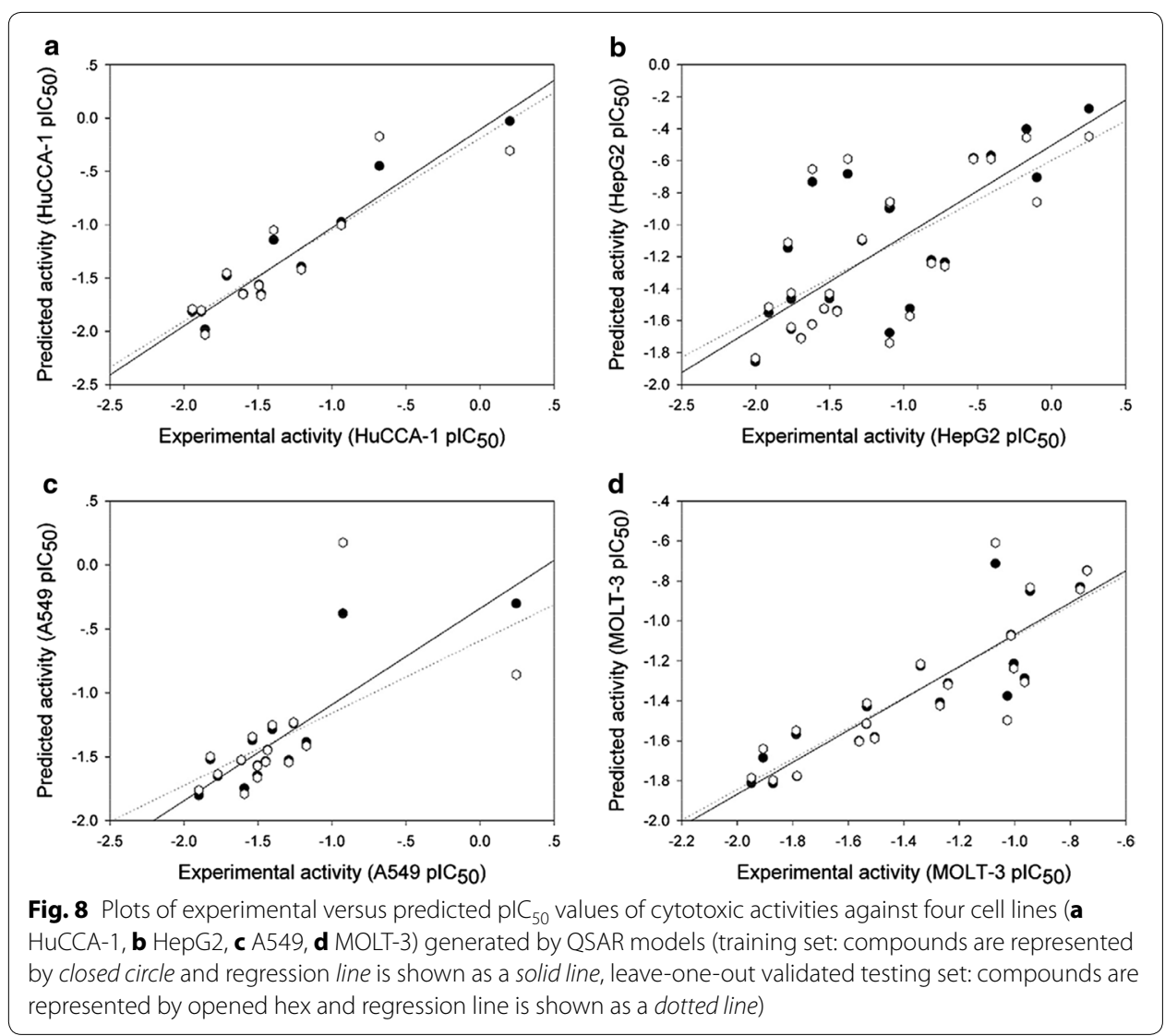

The experimental results (Table 1) showed that the majority of the tested compounds (1-32) were weakly active or inactive against HuCCA-1 cell line except for ester compounds $\mathbf{2 1}$ (highly active), $\mathbf{1}$ (moderately active) and $\mathbf{2 9}$ (moderately active). Particularly, ester compound 21 was the most potent compound affording less $\mathrm{IC}_{50}$ value $(0.63 \mu \mathrm{M})$ than the reference drug, doxorubicin $(0.83 \mu \mathrm{M})$, followed by compound 29 as second ranked. The effect of opened/closed chain core structures were found in compounds $\mathbf{8}$ and $\mathbf{2 1}$ which are the compounds containing the same substituents (R) while bearing different core structures, opened chain (8) or closed chain (21), Fig. 2. Interestingly, the closed chain structure can shift the activity of the compound from inactive (8, opened chain) to highly active (21, closed chain). Moreover, compound 21 exhibited more potent activity than compound $29\left(\mathrm{IC}_{50} 4.79 \mu \mathrm{M}\right)$ indicating that the replacement of $\mathrm{H}$ atoms $\left(\mathrm{R}^{1}\right)$ in aromatic ring by methoxy $\left(\mathrm{OCH}_{3}\right)$ groups can deteriorate the activity. The similar effects can be observed in compound $\mathbf{2 4}$ as compared to compound $\mathbf{1 6}$. However, in some cases, the methoxy substituents $\left(R^{1}\right)$ can improve activity by changing inactive compounds to active compounds such as compound 19 (inactive) to 27 (active), and 22 (inactive) to 30 (active). Certain functional groups (R) were observed to influence the activity of particular compounds. It was found that replacement of naphthalenyl group in compound 3 (inactive) by 7-coumaryl group gives rise to improved activity of compound $11\left(\mathrm{IC}_{50} 16.12 \mu \mathrm{M}\right)$ whereas 4-coumaryl substituent leads to inactive compound 12. In addition, the effect of the closed chain was noted to improve activity of 
4-coumarin analogs as found in compound $23\left(\mathrm{IC}_{50} 24.80 \mu \mathrm{M}\right)$ when compared to opened chain compound 12 (inactive).

The QSAR analysis revealed that descriptors pertaining to the electronegativity $(\mathrm{R} 5 \mathrm{e}+)$ and the number of aromatic esters (nArCOOR) of the compounds influenced the cytotoxic activity against HuCCA-1 cell line, Eq. 1 . The R5e+ descriptor was the most influential descriptor as represented by its high regression coefficient. The negative regression coefficient of $\mathrm{R} 5 \mathrm{e}+(-84.0157)$ and positive regression coefficient of $\mathrm{nAr}$ COOR (1.0288) indicate that low electronegativity and high number of aromatic esters are required for preferable cytotoxic activity. It was observed that compounds with high value of $\mathrm{R} 5 \mathrm{e}+$ exhibited poor activity. For example, ketone 7D $\left(\mathrm{ArCOCF}_{3}\right.$, Fig. 5) with high electronegativity atom (F), which had the highest value of R5e+ (0.057, Additional file 2) amongst all modified compounds, exhibited the worst activity with $\mathrm{pIC}_{50}$ value of -3.915 (Additional file 3). The presence of aromatic esters was found to be important for potent activity as seen in compounds 21, 29 and modified compounds $\left(\mathrm{ArCOOCF}_{3}\right)$ in series 8 (8A-8R) as shown in Fig. 6.

Considering the predicted cytotoxic activity of modified compounds (Additional file 3) and experimental activity of their prototypes (Table 4), the structural modification of compound 1 reduce cytotoxic activity. The experimental inactive compounds ( 2 and 7) afforded modified compounds ( $2 \mathbf{A}-\mathbf{2 R}$ and $7 \mathbf{A}-\mathbf{7 R})$ that possessed weakly to inactive cytotoxic activity. Although the tested compound $\mathbf{8}$ contains aromatic ester, which is represented by nArCOOR descriptor value, it was found to be experimentally inactive. However, the improved activities of modified compounds in series $8(\mathbf{8 A}-\mathbf{8 R})$ were predicted when compared to their inactive prototype (8). Notably, the ester $\mathbf{8} \mathbf{N}\left(\mathrm{pIC}_{50}\right.$ 0.054) was noted as the most potent compound among all modified compound series. It was observed that particular forms (opened/closed chain), substituents $\mathrm{R}$ (phenoxyester), $\mathrm{R}^{1}\left(\mathrm{H}, \mathrm{OH}, \mathrm{OCH}_{3}\right)$ and $\mathrm{R}^{2}$ (1-adamantyl, phenyl) on the meta- and para- triazoles influence the $\mathrm{R} 5 \mathrm{e}+$ value of the compounds in governing their cytotoxic activities. For both para- and meta- modified compounds in series 8, closed chain analogs (8E, $\mathbf{8 G}, \mathbf{8 N}$ and $\mathbf{8 P}$ ) were predicted to exhibit more potent cytotoxic activity (indicated by $\mathrm{pIC}_{50}$ value) than opened chain analogs $(\mathbf{8 A}, \mathbf{8 C}, \mathbf{8 J}$ and, $\mathbf{8 K})$ and the 1-adamantyl $\left(\mathrm{R}^{2}\right)$ derivatives $(\mathbf{8 H}$ and $\mathbf{8 R})$ were predicted to be more active than phenyl $\left(\mathbf{R}^{2}\right)$ derivatives (8D and 8M). In case of the opened chain analogs $(\mathbf{8 A}, 8 \mathrm{~B}, 8 \mathrm{C}, 8 \mathrm{~J}, \mathbf{8 K}$ and $8 \mathrm{~L})$, most of the compounds with para-triazole were predicted as more potent compounds than the compounds with meta-triazole as indicated by $\mathrm{pIC}_{50}$ values i.e., $\mathbf{8 A}(-0.618)>\mathbf{8 J}$ $(-1.038)$ and $8 \mathrm{~B}(-0.786)>\mathbf{8 K}(-1.122)$ except for the case of phenyl $\left(\mathrm{R}^{2}\right)$ compounds in which the large improved activity of meta-triazole $\mathbf{8 M}(-0.618)$ was observed as compared to the para-triazole $\mathbf{8 D}(-2.466)$. In contrast, the closed chain meta-triazole compounds $(\mathbf{8 N}$ and $\mathbf{8 P})$ and 1-adamantyl meta-triazole compound $\left(\mathbf{8 R}, \mathrm{pIC}_{50}-0.282\right)$ were found to exhibit more potent activity than the corresponding closed chain para-triazoles (8E and $8 \mathrm{~F}, \mathrm{pIC}_{50}-0.114$ and -0.786 , respectively) and 1-adamantyl $\left(\mathrm{R}^{2}\right)$ para-triazole compound $\left(\mathbf{8 H}, \mathrm{pIC}_{50}-0.702\right)$.

The most potent ester $\left(\mathrm{COOCF}_{3}\right) \mathbf{8} \mathbf{N}$ is the closed chain meta-triazole $\left(\mathrm{R}^{1}=\mathrm{H}\right)$, which had the lowest R5e+ value (0.022) among the modified compounds. The most potent para-triazole methyl ester $\left(\mathrm{COOCH}_{3}\right) \mathbf{2 1}\left(\mathrm{R}^{1}=\mathrm{H}\right)$ had lower value of $\mathrm{R} 5 \mathrm{e}+(0.023)$ than its methoxy analog $29\left(\mathrm{R}^{1}=\mathrm{OCH}_{3}, \mathrm{R} 5 \mathrm{e}+=0.028\right)$, thereby giving rise to higher potency 
of 21. In contrast, the opened chain para-triazole ester $\left(\mathrm{COOCH}_{3}\right) \mathbf{8}\left(\mathrm{R}^{1}=\mathrm{H}\right)$ exhibited no cytotoxic activity. This could be possibly explained that the cytotoxic activity against HuCCA- 1 cell required the molecule with low electronegativity (R5e+) and less flexibility or more rigidity in interacting with the target site of action as observed in compound 21 comparing to its opened chain analog 8 (inactive compound).

HepG2 cell line:

$$
p I C_{50}=0.0784(R D F 105 m)+5.1878(\text { MATS7m })+1.7524
$$

Results showed that most of the tested compounds (1-32) exhibited more potent cytotoxic activity against HepG2 cell lines than the reference drug, etoposide (Table 1). The closed chain analogs $(\mathbf{1 7}, \mathbf{2 0 - 2 2}$ and 25-30) displayed higher activity as compared to the opened chain analogs $(1,3,11$ and 13). Particularly, compound 28 was noted as the best compound affording less $\mathrm{IC}_{50}$ value $(0.56 \mu \mathrm{M})$ than both reference drugs, etoposide $(30.16 \mu \mathrm{M})$ and doxorubicin $(0.79 \mu \mathrm{M})$. It was found that introducing the $\mathrm{NO}_{2}$ and 4-coumaryl moieties into the phenoxy ring of compound 2 leads to inactive cytotoxic activity of compounds 6 and 12, respectively. It was observed that the substitution of $\mathrm{OCH}_{3}\left(\mathrm{R}^{1}\right)$ on aromatic ring increases cytotoxic activity of the compounds except for compounds 13, 14, and 30. In contrast to HuCCA-1 cell line, the substitution of $\mathrm{OCH}_{3}$ on the aromatic ring $\left(R^{1}\right)$ can markedly increase the value of MATS7 giving rise to an improved activity of compound 29 (MATS7 $=0.040$, Additional file 2 and $\mathrm{IC}_{50}=3.37$, Table 1) when compared to non-substituted $\left(R^{1}=H\right)$ compound 21 (MATS7 $=-0.020$, Additional file 2 and $\mathrm{IC}_{50}=12.36$, Table 1 ) as represented by approximately fourfolds reduced $\mathrm{IC}_{50}$ value. Among the experimental tested compounds, the closed chain derivatives exhibited more potent activity than that of the opened chains, except for closed chain compound 19 (inactive) comparing to its opened chain analog 7 (active). In addition, it should be noted that the para-position of $\mathrm{CH}_{3}$ on the phenoxy ring (28) has greater influence on enhancing the cytotoxic activity of the compound than the orthoposition (27).

The QSAR analysis revealed that mass descriptors i.e., RDF105m and MATS7m, are important descriptors for cytotoxic activity against HepG2 cell line, Eq. 2. The higher regression coefficient of MATS7m (5.1878) indicated its greater influential effect. The QSAR equation indicated that high values of RDF105m and MATS7m are essential for potent cytotoxic activity. For example, the highest RDF value (14.609) together with high MATS7m value (0.064) were found in the most potent compound (28) in the tested series, Additional file 2. Similarly, the most potent predicted cytotoxic activity of the modified compounds was noted in compound $\mathbf{1 P}$ which had the high RDF values of 18.976 .

Improved cytotoxic activities were predicted from all series of the modified compounds in which the most enhanced effects were noted for the modified compounds in series $\mathbf{1}$ and 7. Compound 1P was predicted as the most potent compound of the modified series followed by compound $7 \mathbf{F}$ affording $\mathrm{pIC}_{50}$ values of -0.151 and -0.163 , respectively (Additional file 3). Considering the modified series 1 and 7 (Figs. 3, 5, 7), the 1-adamantyl $\left(\mathbf{R}^{2}\right)$ substituted $(\mathbf{H}$ and $\mathbf{R})$ and closed chain $(\mathbf{E}, \mathbf{F}, \mathbf{G}, \mathbf{N}, \mathbf{P}$ and $\mathbf{Q}$ ) 
compounds are more potent cytotoxic agents against HepG2 cell line than the phenyl $\left(\mathbf{R}^{2}\right)$ substituted ( $\mathbf{D}$ and $\mathbf{M}$ ) and opened chain $(\mathbf{A}, \mathbf{B}, \mathbf{C}, \mathbf{J}, \mathbf{K}$ and $\mathbf{L}$ ) compounds except for the compounds in series $\mathbf{7}(\mathbf{7 N}$ and $\mathbf{7 P})$. The better predicted activities were observed in the opened chain analogs i.e., $7 \mathbf{J}$ and $7 \mathbf{K}$ comparing to the closed chain analogs $7 \mathbf{N}$ and 7P (Additional file 3). For the opened chain in series $\mathbf{1}$ (A, B, C, J, K and L), phenyl $\left(R^{2}\right)$ substituted compounds ( $\mathbf{D}$ and $\left.\mathbf{M}\right)$ and 1-adamantyl $\left(\mathrm{R}^{2}\right)$ substituted compounds $(\mathbf{H}$ and $\mathbf{R})$, it was found that the meta-triazoles (J, K, L, M and $\mathbf{R}$ ) exhibited better activities than the para-triazoles (A, B, C, D and $\mathbf{H})$. For closed chain compounds $(\mathbf{E}, \mathbf{F}, \mathbf{G}$, $\mathbf{N}, \mathbf{P}$ and $\mathbf{Q})$, the meta-triazole of series $\mathbf{1}(\mathbf{1 N}, \mathbf{1 P}$ and $\mathbf{1 Q})$ exerted more potent activity than para-triazole $(\mathbf{1 E}, \mathbf{1 F}$ and $\mathbf{1 G})$. In contrast, the para-triazole of series 7 (7E, 7F and $\mathbf{7 G}$ ) exhibited better activity than the meta-triazole (7N, 7P and 7Q). Particularly, compound $7 \mathbf{F}$ afforded the predicted $\mathrm{pIC}_{50}$ value approximately tenfolds greater than 7P (7F: $\mathrm{pIC}_{50}=-0.163,7 \mathrm{P}: \mathrm{pIC}_{50}=-1.177$, Additional file 3). In addition, the effects of para-triazole with closed chain and 1-adamantyl substituent $\left(\mathrm{R}^{2}\right)$ on improving cytotoxic activity were generally observed via increased MATS7 $m$ values when compared to opened chain and phenyl $\left(\mathrm{R}^{2}\right)$ substituted triazoles whereas that of meta-triazoles were governed by increased RDF105m values when compared to para-triazoles (Additional file 2).

Cytotoxic activity of meta- and para-triazoles are governed by substituents $\mathrm{R}, \mathrm{R}^{1}$ and $\mathrm{R}^{2}$ in providing high values of descriptors (MATS7m and RDF105m) weighted by mass. Obviously, the most potent compounds $\mathbf{2 8}$ and $\mathbf{1 P}$ constitute the same methoxy group $\left(\mathrm{R}^{1}=\mathrm{OCH}_{3}\right)$, and $\mathrm{R}=$ para-methylphenoxymethyl and para-trifluoromethylphenoxy for 28 and $1 P$, respectively. Such substituents $\left(R\right.$ and $R^{1}$ ) enhanced masses on to the triazole core structures.

\section{A549 cell line}

$$
p I C_{50}=1.5979(\text { MATS8v })+0.9251(\text { nArCOOR })-1.7829
$$

Similar to the HuCCA-1 cell line, the majority of the tested compounds (1-32) exhibited weakly active and inactive cytotoxic activities against A549 cell line (Table 1). However, the ester compound 21 (highly active) was noted as the most potent cytotoxic agent followed by ester compound $\mathbf{2 9}$ (moderately active). It was found that closing the ring caused dramatically changes in activity shifting from inactive to active compounds. The notable effect was observed when compared the opened chain ester 8 (inactive) and closed chain ester 21 (highly active). Furthermore, the relative position of $\mathrm{OCH}_{3}$ and $\mathrm{CHO}$ on the substituted phenoxy ring was noted for its influence on cytotoxic activity in which these functional groups were suggested to be placed in para-position to each other as observed for compound $\mathbf{3 1}$ (active) rather than in meta-position as seen in compound 32 (inactive).

The QSAR analysis revealed that van der Waals volume descriptor (MATS8v) and the number of aromatic esters (nArCOOR) are important descriptors for cytotoxic activity against A549 cell line, Eq. 3. The positive regression coefficients of both descriptors indicated that high values are essential for potent cytotoxic activity of the compounds. The effects of substituents $\left(R, R^{1}\right)$ in the tested compound series (1-32) were observed 
via an alteration of MATS8v values. For example, the insertion of carbonyl group to the $\mathrm{CH}_{3}$ group of compound 19 (MATS8v $=0.164$, Additional file 2 and $\mathrm{IC}_{50} 66.30 \mu \mathrm{M}$, Table 1) provided the ketone compound $20\left(\mathrm{IC}_{50} 14.90 \mu \mathrm{M}\right)$ with approximately twofold increased MATS8v value (0.249, Additional file 2) giving rise to its improved activity when compared to compound 19. Interestingly, replacement of $\mathrm{CH}_{3}$ group of compound 19 by $\mathrm{COOCH}_{3}$ gave the most potent compound 21 with the highest MATS8v (0.348) amongst the tested compounds (1-32). The potency of these compounds (19-21) are shown to be $\mathbf{2 1}>\mathbf{2 0}>\mathbf{1 9}$ with the MATS8v values of 0.348, 0.249 and 0.164, respectively. Similar findings of more active compounds possessing the higher MATS8v values were found, for example, compounds $\mathbf{1 0}>\mathbf{9}$ and $\mathbf{2 7}>\mathbf{2 8}$ (Additional file 4).

The structurally modified compounds in series $\mathbf{1}$ and $\mathbf{8}$ were predicted to be more potent compounds than their prototypes. Notably, all of the modified compounds in series $\mathbf{8}$ were predicted as moderately active compounds (Additional file 3) which may be governed by the presence of the aromatic ester in the molecule, as represented by the nArCOOR values (Additional file 2). Ester compounds $\mathbf{8 G}$ and $\mathbf{8 B}$ were noted as the most $($ MATS8v $=0.150)$ and the second most $($ MATS8v $=0.146)$ potent compounds among all modified compounds, respectively (Additional file 3). Apparently, both opened and closed chain para-triazole analogs of the modified compounds in series $\mathbf{8}$ exhibited more potent activities than their meta-triazole analogs (Additional file 5). The closed chain compounds (E, $\mathbf{G}$ and N, Fig. 6) were predicted to be more active than the opened chain compounds (A, C and J, Fig. 6) except for the opened chain analogs 8B and $\mathbf{8 K}$ were predicted as more potent compounds than the closed chain derivatives $\mathbf{8 F}$ and $\mathbf{8 P}$, Additional file 4. However, effect of opened/closed chain were not clearly observed for $\mathrm{OH}\left(\mathrm{R}^{1}\right)$ substituted compounds $\mathbf{8 L}$ (opened chain, $\mathrm{pIC}_{50}=-0.779$, Additional file 3 ) and $8 \mathrm{Q}$ (closed chain, $\mathrm{pIC}_{50}=-0.778$, Additional file 3 ) as represented by their comparable $\mathrm{pIC}_{50}$ values. For both para- and meta- analogs of all modified series (Fig. 6), 1-adamantyl $\left(R^{2}\right)$ substituted compounds exhibited more potent activity than phenyl $\left(R^{2}\right)$ substituted compounds, except for series 1 . The phenyl $\left(R^{2}\right)$ substituted compound of meta-series, compound $\mathbf{1 M}$, was more potent than its 1-adamantyl $\left(R^{2}\right)$ analog 1R (Additional file 4). No effect of changing substituted ring type $\left(R^{2}\right)$ was found for para-series as observed from comparable cytotoxic activities of compounds $\mathbf{1 H}$ and 1D, Additional file 4.

The most potent esters $21\left(\mathrm{COOCH}_{3}, \mathbf{R}^{1}=\mathrm{H}\right)$ and $\mathbf{8 G}\left(\mathrm{COOCF}_{3}, \mathrm{R}^{1}=\mathrm{OH}\right)$ are paratriazoles, in which both compounds had the highest values of MATS8v in their tested and modified series compounds, respectively.

MOLT-3 cell line

$$
p I C_{50}=1.0649(\text { Lop })+10.3977(R 7 m)-5.6832
$$

Among the tested compounds (1-32), only compounds 8, 9, 31 and 32 were noted as moderately active cytotoxic agents against MOLT-3 cell line while the rest were listed as inactive to weakly active compounds. The findings suggested that the substitution of $\mathrm{CO}_{2} \mathrm{CH}_{3}, \mathrm{OCH}_{3}$ and $\mathrm{CHO}$ moieties on the phenoxylmethyl group (R) may essential for cytotoxic activity of the compounds. Interestingly, the effects of certain moieties and 
isomeric forms on cytotoxic activity against the MOLT-3 cell line were found in contrast to other tested cell lines i.e., HuCCA-1, HepG2 and A549. Particularly, $m$-substitution of $\mathrm{OCH}_{3}$ and $\mathrm{CHO}$ on phenoxy (R) group exerted the most potent activity as noted for closed chain compound $\mathbf{3 2}$ comparing to $p$-substitution of compound 31 (Additional file 4). Similar isomeric effect of $\mathrm{OCH}_{3}$ and $\mathrm{CHO}$ was found in opened chain analogs of meta- (9) and para- (10) in which 9 exhibited more potent activity than 10. In addition, the replacement of naphthalenyl moiety in the opened chain triazoles (3) by 7-coumaryl moiety gave compound 11 with loss of the cytotoxic activity $(3>11)$. However, more potent activity can be obtained by substitution of 4-coumaryl rather than 7-coumaryl $(12$ > 11), Table 1. Furthermore, opened chain triazole of 4-coumaryl (12) exhibited better activity when compared to the same substitution (R) on the closed chain triazole (23).

The QSAR analysis indicated that topological index (Lop) and atomic masses descriptor $(\mathrm{R} 7 \mathrm{~m})$ were influential descriptors for affecting the cytotoxic activity against MOLT-3 cell line, Eq. 4. Regarding the regression coefficient of R7m, the importance of the atomic masses of the compounds were noted. The effect of functional group substitution affecting the $R 7 \mathrm{~m}$ values were obviously seen in closed chain $\left(\mathrm{R}^{1}=\mathrm{OMe}\right)$ compounds 31 and 32 in which both compounds possess the same value of Lop (0.876, Additional file 2) but different values of $\mathrm{R} 7 \mathrm{~m}(\mathbf{3 1}=0.377, \mathbf{3 2}=0.385$, Additional file 2$)$. It was observed that the relative positions of $\mathrm{OCH}_{3}$ and $\mathrm{CHO}$ on the phenoxylmethyl ring $(\mathrm{R})$ affects the $\mathrm{R} 7 \mathrm{~m}$ values. The higher value of $\mathrm{R} 7 \mathrm{~m}$ was observed when these two functional groups are placed in meta-position to each other thereby giving rise to more potent activity (32 > 31, Fig. 2, Additional file 3). Similar substitution effects of $\mathrm{OCH}_{3}$ and $\mathrm{CHO}$ on the $R$ group afforded the same Lop value $(0.740)$ were noted for opened chain $\left(R^{1}=H\right)$ compounds 9 and 10. However, meta-substitution of $\mathrm{OCH}_{3}$ and $\mathrm{CHO}(9)$ displayed higher activity with relative lower $\mathrm{R} 7 \mathrm{~m}$ value as compared to para-substitution on the $\mathrm{R}$ group of $\mathbf{1 0 .}$

It was found that the structural modifications can improve the activities of all modified compounds (Table 4 and Additional file 3) when compared to their prototypes (1, 2, 7 and $\mathbf{8}$ ) except for 1-adamantyl analog $\left(\mathrm{R}^{2}\right)$ of compound $7,7 \mathbf{H}$ affording $\mathrm{pIC}_{50}$ value of -1.865 (Additional file 3) while that of 7 was -1.513 (Table 4). The best enhancing effects were found in modified compounds series 8 in which most of the compounds were predicted as highly active (Additional file 3 ). Interestingly, closed chain $\left(\mathrm{R}^{1}=\mathrm{OH}\right.$, $\mathrm{R}=$ ortho-ester) of $m$-triazole compound $8 \mathrm{Q}(\mathrm{R} 7 \mathrm{~m}=0.537)$ and of $p$-triazole $\mathbf{8 G}$ $(\mathrm{R} 7 \mathrm{~m}=0.519)$ had the same value of Lop (0.983), and were found to be the most and the second most potent compounds of all modified series, respectively. However, none of them exhibited more potent activity than the reference drug, etoposide. Considering the modified compounds series 8 , the closed chain triazole derivatives (8F, 8G, 8P and 8Q) exhibited more potent cytotoxic activity than the opened chain analogs except for $\mathbf{8 A}$ and $\mathbf{8 J}(\mathbf{8 A}>\mathbf{8 E}$ and $\mathbf{8 J}>\mathbf{8 N})$. The notably enhanced effect was observed in the closed chain hydroxyl $\left(\mathrm{R}^{1}\right)$ derivative $8 \mathrm{Q}$ as represented by its 8.61 -folds $\mathrm{pIC}_{50}$ value $(0.947)$ greater than the opened chain compound $\mathbf{8 L}$ (0.110), Additional file 3.

A variety of structural modification effects on cytotoxic activity against the MOLT-3 cell line can be observed through para- and meta-triazoles (Additional file 5). It was noted that both meta- and para-triazoles influence the cytotoxic activity via the 
alteration of $\mathrm{R} 7 \mathrm{~m}$ values in which the more active compounds possess the higher values of R7m but equal Lop as compared to the less active ones (Additional files 2, 3). For example, meta-triazole compound $\mathbf{8 M}\left(\mathrm{R}^{2}=\right.$ phenyl) with higher $\mathrm{R} 7 \mathrm{~m}$ value was approximately twofold more potent than para-triazole of phenyl $\left(\mathrm{R}^{2}\right)$ compound $8 \mathrm{D}(\mathrm{R} 7 \mathrm{~m}$; $\mathbf{8 M}=0.397, \mathbf{8 D}=0.365$, Additional file 2 and $\mathrm{pIC}_{50} ; \mathbf{8 M}=-0.485, \mathbf{8 D}=-0.818$, Additional file 3). The 1-adamantyl $\left(\mathrm{R}^{2}\right)$ substitution in para-triazole core structure enhances cytotoxic activity as represented by 2.456 folds increased $\mathrm{pIC}_{50}$ value of compound $\mathbf{8 H}$ $\left(\mathrm{pIC}_{50}=-0.333\right.$, Additional file 3$)$ as compared to the phenyl $\left(\mathrm{R}^{2}\right)$ substituted paracompound $8 \mathrm{D}\left(\mathrm{pIC}_{50}=-0.818\right.$, Additional file 3$)$. In contrast, the phenyl $\left(\mathrm{R}^{2}\right)$ substituted meta-triazole compound $\mathbf{8} \mathbf{M}$ exhibited better activity than the 1-adamantyl $\left(R^{2}\right)$ substituted meta-triazole compound $\mathbf{8 R}\left(\mathrm{pIC}_{50}: \mathbf{8} \mathbf{M}=-0.485, \mathbf{8 R}=-0.645\right.$, Additional file 3).

The most potent compounds ( 32 and $\mathbf{8 Q}$ ) against MOLT-3 cell are para-triazole $\left(\mathrm{R}^{1}=\mathrm{OCH}_{3}, \mathrm{R}=\right.$ phenoxyaldehyde $)$ and meta-triazole $\left(\mathrm{R}^{1}=\mathrm{OH}, \mathrm{R}=\right.$ phenoxyester $)$, respectively. It is notable that a carbonyl $(\mathrm{CO})$ group of the aldehyde $\mathbf{3 2}$ may act as electrophilic center in interacting with nucleophile at the target site of action. Similar interaction could possibly be seen in the $\mathrm{CO}$ group of ester $\mathbf{8 Q}$ with nucleophilic site of action. These findings suggested that particular isomers in combination with certain functional groups $\left(R^{2}\right)$ are required for preferable cytotoxic activity of the compounds. The promising compounds to be further developed as anticancer agents against each cancer cell line are summarized in Table 5, obviously, meta- triazoles $\mathbf{8 N}, \mathbf{1 P}$ and $\mathbf{8 Q}$ for HuCCA-1, HepG2 and MOLT-3 cell lines, respectively, and para- triazole 8G for A549 cell line.

\section{Conclusion}

Understanding structure-activity relationships of the compounds is essential for efficacious design and development of drugs. Herein, the QSAR was used as a tool for investigating the effects of structural modifications on the cytotoxic activity of the triazole derivatives. Four QSAR models were successfully constructed using the chemical structures and the experimental cytotoxic activities of a set of triazole derivatives (1-32). The acceptable predictive performances were obtained affording $R_{\mathrm{CV}}$ values ranging from 0.5958 to 0.8957 and $\mathrm{RMSE}_{\mathrm{CV}}$ ranging from 0.2070 to 0.4526 . The QSAR models revealed a set of important descriptors that represented distinct properties influencing the cytotoxic activity against particular cell lines i.e., electronegativity, number of aromatic ester, van der Waals volume, topological indice and atomic masses. The effects of meta-/para-triazoles, the opened/closed chain core structure and particular substituents $\left(R, R^{1}, R^{2}\right)$ affecting the cytotoxic activities of the compounds were investigated by virtual construction of an additional set of structurally modified compounds $(\mathbf{1 A}-\mathbf{1 R}$, 2A-2R, 7A-7R and 8A-8R) in which their cytotoxic activities were predicted using the constructed QSAR models obtained from the tested compounds. The findings indicated a set of potential compounds for further development as summarized in Table 5. The study provided insights into the SAR of the triazole derivatives and their cytotoxic activities. The influential moieties and isomers for preferable activity, and a set of promising compounds for further development were indicated for the benefit of guiding the design, synthesis and development of novel triazole-based anticancer agents. 
Table 5 A summary of potential compounds for further development

\begin{tabular}{|c|c|c|c|c|c|c|}
\hline Cell line & $\begin{array}{l}\text { Tested / } \\
\text { modified }\end{array}$ & Compound & $\begin{array}{c}\text { Cytotoxic activity } \\
\left(\text { pIC }_{50}\right)\end{array}$ & $\begin{array}{l}\text { Triazole } \\
\text { position }\end{array}$ & $\begin{array}{c}\text { Opened/closed } \\
\text { chain }\end{array}$ & Chemical structure \\
\hline \multirow[t]{2}{*}{ HuCCA-1 } & Tested & 21 & $0.201^{\mathrm{a}, \mathrm{c}}$ & para & Closed & \\
\hline & Modified & $8 \mathrm{~N}$ & $0.054^{\mathrm{a}}$ & meta & Closed & \\
\hline \multirow[t]{2}{*}{ HepG2 } & Tested & 28 & $0.252^{\mathrm{a}, \mathrm{c}}$ & para & Closed & \\
\hline & Modified & $1 \mathrm{P}$ & $-0.151^{b}$ & meta & Closed & \\
\hline \multirow[t]{2}{*}{$A 549$} & Tested & 21 & $0.244^{a}$ & para & Closed & \\
\hline & Modified & $8 \mathrm{G}$ & $-0.618^{b}$ & para & Closed & \\
\hline \multirow[t]{2}{*}{$M O L T-3$} & Tested & 32 & $-0.740^{b}$ & para & Closed & \\
\hline & Modified & $8 Q$ & $0.947^{\mathrm{a}}$ & meta & Closed & \\
\hline
\end{tabular}

a Highly active

b Moderately active

c Potent than reference drug

\section{Methods}

Conceptually, a series of predictive QSAR models were constructed using data sets obtained from experimentally tested compounds (1-32, Figs. 1, 2) (Pingaew et al. 2014a, b) and were subsequently used for prediction of additional structurally modified compounds (1A-1R, 2A-2R, 7A-7R and 8A-8R, Fig. 3, 4, 5, 6) generated in silico. The conceptual framework is shown in Fig. 9. Initially, the molecular structures of the tested compounds (1-32) were drawn, geometrically optimized and calculated to obtain a large set of descriptor values. Hence, feature selection was performed to select only informative ones which were further used as predictors $(X)$ to predict anticancer activity $(Y)$. These $X$ (descriptors) and $Y$ (cytotoxic activity) blocks of data were subsequently used for development of QSAR models. Likewise, the construction, geometrical optimization 


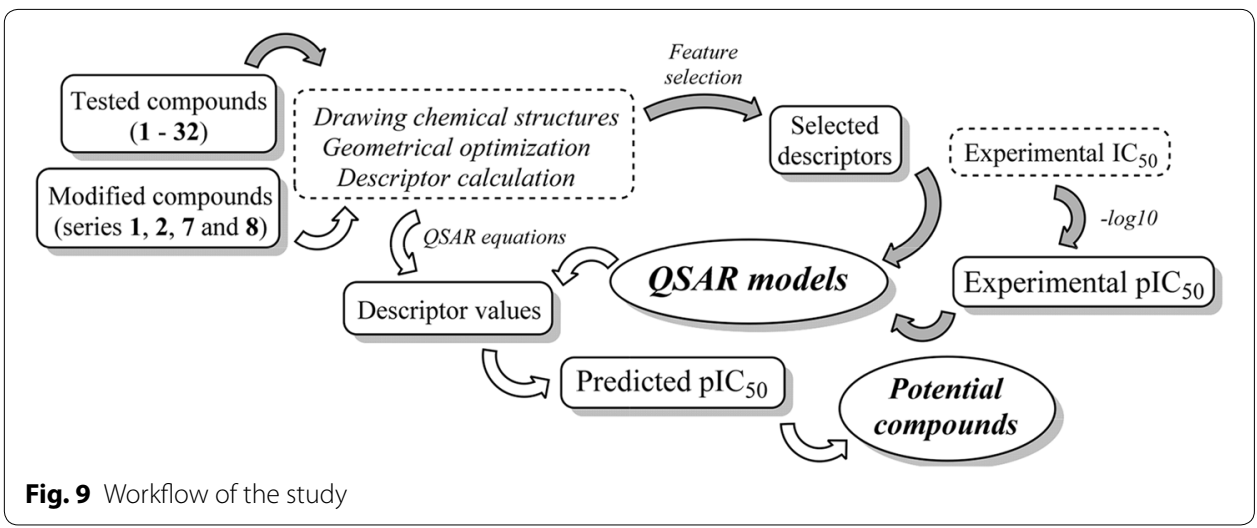

and calculation were performed in the same manner with the structurally modified compounds (1A-1R, 2A-2R, 7A-7R and 8A-8R) to obtain their descriptor values. Finally, the QSAR equations constructed by the tested compounds (1-32) were used to calculate predicted activities of modified compounds $(\mathbf{1 A}-\mathbf{1 R}, \mathbf{2 A}-\mathbf{2 R}, 7 \mathbf{A}-\mathbf{7} \mathbf{R}$ and $\mathbf{8 A}-\mathbf{8 R})$.

\section{Data sets}

A set of triazole derivatives (1-32) and their experimental $\mathrm{IC}_{50}$ values against four cancer cell lines i.e., HuCCA-1, HepG2, A549 and MOLT-3 (Table 1) were obtained from literature reported by our research group (Pingaew et al. 2014a, b). In order to obtain normal distribution of data points, the $\mathrm{IC}_{50}$ values were converted to $\mathrm{PIC}_{50}$ values by taking the negative logarithm to the base of $10\left(-\log \mathrm{IC}_{50}\right)$. With respect to the anticancer activity against four cancer cell lines, four data sets were arranged for the construction of separated QSAR models. For each data set, the compounds exhibited inactive cytotoxic activity were excluded from the analysis.

\section{Molecular structure optimization and descriptor calculation}

The rationale for geometrical optimization is to obtain low-energy conformers for investigated compounds that will subsequently be used for calculation of molecular descriptors. Chemical structures of the 32 tested compounds (1-32) and 64 virtually modified compounds (1A-1R, 2A-2R, 7A-7R and 8A-8R) were drawn by the GaussView software (Dennington et al. 2003) and initially geometrically optimized using Gaussian 09 (Frisch et al. 2009) at the semi-empirical Austin Model 1 (AM1) level followed by density functional theory (DFT) calculation using the Becke's three-parameter hybrid method with the Lee-Yang-Parr correlation functional (B3LYP) together with the 6-31 $\mathrm{g}(\mathrm{d})$ level. A set of quantum chemical descriptors consisted of the mean absolute atomic charge $\left(Q_{\mathrm{m}}\right)$, total energy $\left(E_{\text {total }}\right)$, total dipole moment $(\mu)$, highest occupied molecular orbital energy $\left(E_{\mathrm{HOMO}}\right)$, lowest unoccupied molecular orbital energy $\left(E_{\mathrm{LUMO}}\right)$, energy difference of $\mathrm{HOMO}$ and LUMO (HOMO-LUMO ${ }_{\mathrm{Gap}}$ ), electron affinity (EA), ionization potential (IP), Mulliken electronegativity $(\chi)$, hardness $(\eta)$, softness $(S)$, electrophilic index $\left(\omega_{\mathrm{i}}\right)$ and electrophilicity $(\omega)$ were extracted using an in-house developed script. A set of 3224 molecular descriptors were calculated from optimized molecular structures using Dragon software (version 5.5) (Talete 2007). The molecular descriptors obtained from Dragon are comprised of 22 classes as follows: Constitutional descriptors, 
Topological descriptors, Walk and path counts, Connectivity indices, Information indices, 2D autocorrelation, Edge adjacency indices, Burden eigenvalues, Topological charge indices, Eigenvalue-based indices, Randic molecular profiles, Geometrical descriptors, RDF descriptors, 3D-MoRSE descriptors, WHIM descriptors, GETAWAY descriptors, Functional group counts, Atom-centred fragments, Charge descriptors, Molecular properties, 2D binary fingerprints and 2D frequency fingerprints.

\section{Feature selection}

The correlation-based feature selection was performed to select informative descriptors from a large set of calculated descriptors. Initially, the pair-correlation of each descriptor value and bioactivity $\left(\mathrm{pIC}_{50}\right)$ was calculated from an initial set of descriptors consisting of 13 quantum chemical descriptors and 3224 molecular descriptors. The correlation coefficient ( $r$ ) value of 0.6 was used as a cut-off value for initial selection. Descriptors with $|\mathrm{r}|<0.6$ were considered as low correlated descriptors and were excluded from the study whereas those with $|\mathrm{r}| \geq 0.6$ were selected for further selection process. The remaining descriptors along with their bioactivity $\left(\mathrm{pIC}_{50}\right)$ were used as an input data for feature selection by stepwise multiple linear regression (MLR) as implemented in SPSS statistics 18.0 (SPSS statistics 18.0 2009). Finally, a set of important descriptors were obtained for multivariate analysis using MLR.

\section{Multivariate analysis using MLR}

Multivariate analysis was performed by MLR using selected descriptors as independent variables $(X)$ and $\mathrm{pIC}_{50}$ values as dependent variable $(Y)$. The MLR models were constructed by Waikato Environment for Knowledge Analysis (WEKA) version 3.4.5 (Witten et al. 2011) according to the following equation:

$$
Y=B_{0}+\sum B n X n
$$

where $Y$ is the $\mathrm{pIC}_{50}$ values of compounds, $B_{0}$ is the intercept and $B_{n}$ are the regression coefficient of descriptors $X_{n}$.

\section{Data sampling}

The data set was divided into 2 subsets i.e., training set and testing set by means of leaveone-out cross validation (LOO-CV). Conceptually, one sample was removed from the whole data set $(N)$ and were used as the testing set while the remaining samples $(N-1)$ were used as the training set. The same process was continued until every sample in the data set was iteratively used as the testing set to predict $Y$ variable.

\section{Evaluating the performance of QSAR models}

The predictive performances of the QSAR models were assessed by two statistical parameters i.e., correlation coefficient $(R)$ and root mean square error (RMSE). The first parameter $(R)$ represented the predictive performance whereas the later (RMSE) represented predictive error of the models. 


\title{
Prediction of structurally modified compounds by the constructed QSAR models
}

Regarding the obtained QSAR equations, the descriptor values of 64 structurally modified compounds (1A-1R, 2A-2R, 7A-7R and $\mathbf{8 A - 8 R}$ ) obtained from Gaussian and Dragon calculations were used as independent variable $(X)$ for computing their predicted anticancer activity $\left(\mathrm{pIC}_{50}\right.$ values) against the four tested cancer cell lines.

\section{Additional files}

Additional file 1: Analytical data of the reported compounds.

Additional file 2: Table S1. Values of informative molecular descriptors of tested (1-32) and virtually modified compounds (1A-1R, 2A-2R, 7A-7R and 8A-8R).

Additional file 3: Table S2. Predicted cytotoxic activity $\left(p / C_{50}\right)$ of modified compounds (1A-1R, 2A-2R, 7A-7R and $\mathbf{8 A - 8 R}$ ) and experimental cytotoxic activity of reference drugs.

Additional file 4: Table S3. A summary of substituent effects on cytotoxic activity of four cancer cell lines.

Additional file 5: Table S4. Comparison of meta- and para-triazole derivatives focused on the modified compound series with the best improved activity.

\begin{abstract}
Authors' contributions
VP performed the QSAR analysis, participated in interpretation of results and drafted the manuscript. RP participated in the design of the study, interpretation of the results, and proofread the manuscript. NA participated in QSAR analysis and in preparing the manuscript, AW participated in QSAR analysis and proofread the manuscript. CN participated in the design of the study and proofread the manuscript. SP participated in the design of the study and interpretation of the results, and proofread the manuscript. SR and VP conceived of the study and final proofread the manuscript. All authors read and approved the final manuscript.
\end{abstract}

\section{Author details}

${ }^{1}$ Department of Clinical Microbiology and Applied Technology, Faculty of Medical Technology, Mahidol University, Bangkok 10700, Thailand. ${ }^{2}$ Center of Data Mining and Biomedical Informatics, Faculty of Medical Technology, Mahidol University, Bangkok 10700, Thailand. ${ }^{3}$ Department of Chemistry, Faculty of Science, Srinakharinwirot University, Bangkok 10110, Thailand. ${ }^{4}$ Department of Clinical Chemistry, Faculty of Medical Technology, Mahidol University, Bangkok 10700, Thailand. ${ }^{5}$ Laboratory of Medicinal Chemistry, Chulabhorn Research Institute, Bangkok 10210, Thailand. ${ }^{6}$ Program in Chemical Biology, Chulabhorn Graduate Institute, Bangkok 10210, Thailand. ${ }^{7}$ Center of Excellence On Environmental Health and Toxicology, Commission On Higher Education (CHE), Ministry of Education, Bangkok, Thailand.

\section{Acknowledgements}

This project is supported by the Office of the Higher Education Commission, Mahidol University under the National Research Universities Initiative and Annual Government Grant under Mahidol University (2556-2558 B.E.). We would like to thank the research grant from Srinakharinwirot University under the Government Budget (2559 B.E.).

\section{Compliance with ethical guidelines}

\section{Competing interests}

The authors declare that they have no competing interests.

Received: 19 August 2015 Accepted: 17 September 2015

Published online: 05 October 2015

\section{References}

Agalave SG, Maujan SR, Pore VS (2011) Click chemistry: 1,2,3-triazoles as pharmacophores. Chem Asian J 6:2696-2718. doi:10.1002/asia.201100432

Almasirad A, Tabatabai SA, Faizi M, Kebriaeezadeh A, Mehrabi N, Dalvandi A, Shafiee A (2004) Synthesis and anticonvulsant activity of new 2-substituted-5-[2-(2-fluorophenoxy)phenyl]-1,3,4-oxadiazoles and 1,2,4-triazoles. Bioorg Med Chem Lett 14:6057-6059. doi:10.1016/j.bmcl.2004.09.072

Amir M, Shikha K (2004) Synthesis and anti-inflammatory, analgesic, ulcerogenic and lipid peroxidation activities of some new 2-[(2,6-dichloroanilino) phenyl]acetic acid derivatives. Eur J Med Chem 39:535-545. doi:10.1016/j. ejmech.2004.02.008

Anderson AC (2003) The process of structure-based drug design. Chem Biol 10:787-797. doi:10.1016/j. chembiol.2003.09.002

Barker A, Kettle JG, Nowak T, Pease JE (2013) Expanding medicinal chemistry space. Drug Discov Today 18:298-304. doi:10.1016/j.drudis.2012.10.008

Chrysina ED, Bokor E, Alexacou KM, Charavgi MD, Oikonomakos GN, Zographos SE, Leonidas DD, Oikonomakos NG, Somsák L (2009) Amide-1,2,3-triazole bioisosterism: the glycogen phosphorylase case. Tetrahedron Asymmetry 20:733-740. doi:10.1016/j.tetasy.2009.03.021 
Dandapani S, Marcaurelle LA (2010) Grand challenge commentary: accessing new chemical space for 'undruggable' targets. Nat Chem Biol 6:861-863. doi:10.1038/nchembio.479

Dennington IIR, Keith T, Millam J, Eppinnett K, Hovell WL, Gilliland R (2003) GaussView, Version 3.09. Semichem Shawnee Mission, KS, USA

Frisch MJ, Trucks GW, Schlegel HB, Scuseria GE, Robb MA, Cheeseman JR, Scalmani G, Barone V, Mennucci B, Petersson GA, Nakatsuji H, Caricato M, Li X, Hratchian HP, Izmaylov AF, Bloino J, Zheng G, Sonnenberg JL, Hada M, Ehara M, Toyota K, Fukuda R, Hasegawa J, Ishida M, Nakajima T, Honda Y, Kitao O, Nakai H, Vreven T, Jr. JAM, Peralta JE, Ogliaro F, Bearpark M, Heyd JJ, Brothers E, Kudin KN, Staroverov VN, Kobayashi R, Normand J, Raghavachari K, Rendell A, Burant JC, Iyengar SS, Tomasi J, Cossi M, Rega N, Millam JM, Klene M, Knox JE, Cross JB, Bakken V, Adamo C, Jaramillo J, Gomperts R, Stratmann RE, Yazyev O, Austin AJ, Cammi R, Pomelli C, Ochterski JW, Martin RL, Morokuma K, Zakrzewski VG, Voth GA, Salvador P, Dannenberg JJ, Dapprich S, Daniels AD, Farkas Ö, Foresman JB, Ortiz JV, Cioslowski J, Fox DJ (2009). Gaussian Inc., Wallingford CT

Hansch C, Leo A, Mekapati SB, Kurup A (2004) QSAR and ADME. Bioorg Med Chem 12:3391-3400. doi:10.1016/j. bmc.2003.11.037

Holla BS, Poojary KN, Rao BS, Shivananda MK (2002) New bis-aminomercaptotriazoles and bis-triazolothiadiazoles as possible anticancer agents. Eur J Med Chem 37:511-517. doi:10.1016/S0223-5234(02)01358-2

Hughes JP, Rees S, Kalindjian SB, Philpott KL (2011) Principles of early drug discovery. Br J Pharmacol 162:1239-1249. doi:10.1111/j.1476-5381.2010.01127.x

Kaul PN (1998) Drug discovery: past, present and future. Prog Drug Res 50:9-105. doi:10.1007/978-3-0348-8833-2_1

Kumar SS, Kavitha HP (2013) Synthesis and biological applications of triazole derivatives_a review. Mini Rev Org Chem 10:40-65. doi:10.2174/1570193X11310010004

Manclús JJ, Moreno MJ, Plana E, Montoya Á (2008) Development of monoclonal immunoassays for the determination of triazole fungicides in fruit juices. J Agric Food Chem 56:8793-8800. doi:10.1021/jf801187b

Masuda K, Toga T, Hayashi N (1975) Synthesis of 3-morpholino-N-ethoxycarbonyl sydnonimine-5-14C (sin-10-14C). J Labelled Compd 11:301-304. doi:10.1002/jlcr.2590110219

Mathers CD, Loncar D (2006) Projections of global mortality and burden of disease from 2002 to 2030. PLoS Med 3:e442. doi:10.1371/journal.pmed.0030442

Nantasenamat C, Isarankura-Na-Ayudhya C, Naenna T, Prachayasittikul V (2009) A practical overview of quantitative structure-activity relationship. EXCLI J 8:74-88

Nantasenamat C, Isarankura-Na-Ayudhya C, Prachayasittikul V (2010) Advances in computational methods to predict the biological activity of compounds. Expert Opin Drug Discov 5:633-654. doi:10.1517/17460441.2010.492827

Nantasenamat C, Monnor T, Worachartcheewan A, Mandi P, Isarankura-Na-Ayudhya C, Prachayasittikul V (2014) Predictive QSAR modeling of aldose reductase inhibitors using Monte Carlo feature selection. Eur J Med Chem 76:352-359. doi:10.1016/j.ejmech.2014.02.043

Pérez-Sacau E, Díaz-Peñate RG, Estévez-Braun A, Ravelo AG, García-Castellano JM, Pardo L, Campillo M (2007) Synthesis and pharmacophore modeling of naphthoquinone derivatives with cytotoxic activity in human promyelocytic leukemia HL-60 cell line. J Med Chem 50:696-706. doi:10.1021/jm060849b

Perkins R, Fang H, Tong W, Welsh WJ (2003) Quantitative structure-activity relationship methods: perspectives on drug discovery and toxicology. Environ Toxicol Chem 22:1666-1679. doi:10.1897/01-171

Pingaew R, Mandi P, Nantasenamat C, Prachayasittikul S, Ruchirawat S, Prachayasittikul V (2014a) Design, synthesis and molecular docking studies of novel N-benzenesulfonyl-1,2,3,4-tetrahydroisoquinoline-based triazoles with potential anticancer activity. Eur J Med Chem 81:192-203. doi:10.1016/j.ejmech.2014.05.019

Pingaew R, Prachayasittikul S, Ruchirawat S, Prachayasittikul V (2014b) Synthesis and cytotoxicity of novel 4-(4-(substituted)-1H-1,2,3-triazol-1-yl)-N-phenethylbenzenesulfonamides. Med Chem Res 23:1768-1780. doi:10.1007/s00044-013-0777-z

Pingaew R, Prachayasittikul V, Mandi P, Nantasenamat C, Prachayasittikul S, Ruchirawat S, Prachayasittikul V (2015) Synthesis and molecular docking of 1,2,3-triazole-based sulfonamides as aromatase inhibitors. Bioorg Med Chem 23:3472-3480. doi:10.1016/j.bmc.2015.04.036

Prachayasittikul V, Pingaew R, Worachartcheewan A, Nantasenamat C, Prachayasittikul S, Ruchirawat S, Prachayasittikul V (2014) Synthesis, anticancer activity and QSAR study of 1,4-naphthoquinone derivatives. Eur J Med Chem 84:247-263. doi:10.1016/j.ejmech.2014.07.024

Prasad DJ, Ashok M, Karegoudar P, Poojary B, Holla BS, Kumari NS (2009) Synthesis and antimicrobial activities of some new triazolothiadiazoles bearing 4-methylthiobenzyl moiety. Eur J Med Chem 44:551-557. doi:10.1016/j. ejmech.2008.03.025

Shivarama Holla B, Gonsalves R, Shenoy S (1998) Studies on some N-bridged heterocycles derived from bis-[4-amino5-mercapto-1,2,4-triazol-3-yl] alkanes. II Farmaco 53(53):574-578. doi:10.1016/S0014-827X(98)00068-8

Shivarama Holla B, Veerendra B, Shivananda MK, Poojary B (2003) Synthesis characterization and anticancer activity studies on some Mannich bases derived from 1,2,4-triazoles. Eur J Med Chem 38:759-767. doi:10.1016/ S0223-5234(03)00128-4

Soerjomataram I, Lortet-Tieulent J, Ferlay J, Forman D, Mathers C, Parkin D, Bray F (2012) Estimating and validating disability-adjusted life years at the global level: a methodological framework for cancer. BMC Med Res Methodol 12:125. doi:10.1186/1471-2288-12-125

(2009) PASW Statistics 18, Release version 18.0.0, SPSS Inc., Chicago, IL, USA. http://www.spss.com

Talete (2007) Dragon for Windows (Software for Molecular Descriptor Calculations), Version 5.5. Milan, Italy Topliss JG (1972) Utilization of operational schemes for analog synthesis in drug design. J Med Chem 15:1006-1011

Topliss JG (1977) A manual method for applying the Hansch approach to drug design. J Med Chem 20:463-469

Turan-Zitouni G, Kaplancikli ZA, Yildiz MT, Chevallet P, Kaya D (2005) Synthesis and antimicrobial activity of 4-phenyl/ cyclohexyl-5-(1-phenoxyethyl)-3-[N-(2-thiazolyl)acetamido]thio-4H-1,2,4- triazole derivatives. Eur J Med Chem 40:607-613. doi:10.1016/j.ejmech.2005.01.007

Vatmurge NS, Hazra BG, Pore VS, Shirazi F, Chavan PS, Deshpande MV (2008) Synthesis and antimicrobial activity of $\beta$-lactam-bile acid conjugates linked via triazole. Bioorg Med Chem Lett 18:2043-2047. doi:10.1016/j. bmcl.2008.01.102 
Vos T, Flaxman AD, Naghavi M, Lozano R, Michaud C, Ezzati M, Shibuya K, Salomon JA, Abdalla S, Aboyans V, Abraham J, Ackerman I, Aggarwal R, Ahn SY, Ali MK, AlMazroa MA, Alvarado M, Anderson HR, Anderson LM, Andrews KG, Atkinson C, Baddour LM, Bahalim AN, Barker-Collo S, Barrero LH, Bartels DH, Basáñez M-G, Baxter A, Bell ML, Benjamin EJ, Bennett D, Bernabé E, Bhalla K, Bhandari B, Bikbov B, Abdulhak AB, Birbeck G, Black JA, Blencowe H, Blore JD, Blyth F, Bolliger I, Bonaventure A, Boufous S, Bourne R, Boussinesq M, Braithwaite T, Brayne C, Bridgett L, Brooker S, Brooks P, Brugha TS, BryanHancock C, Bucello C, Buchbinder R, Buckle G, Budke CM, Burch M, Burney P, Burstein R, Calabria B, Campbell B, Canter CE, Carabin H, Carapetis J, Carmona L, Cella C, Charlson F, Chen H, Cheng AT-A, Chou D, Chugh SS, Coffeng LE, Colan SD, Colquhoun S, Colson KE, Condon J, Connor MD, Cooper LT, Corriere M, Cortinovis M, de Vaccaro KC, Couser W, Cowie BC, Criqui MH, Cross M, Dabhadkar KC, Dahiya M, Dahodwala N, Damsere-Derry J, Danaei G, Davis A, De Leo D, Degenhardt L, Dellavalle R, Delossantos A, Denenberg J, Derrett S, Des Jarlais DC, Dharmaratne SD, Dherani M, Diaz-Torne C, Dolk H, Dorsey ER, Driscoll T, Duber H, Ebel B, Edmond K, Elbaz A, Ali SE, Erskine H, Erwin PJ, Espindola P, Ewoigbokhan SE, Farzadfar F, Feigin V, Felson DT, Ferrari A, Ferri CP, Fèvre EM, Finucane MM, Flaxman S, Flood L, Foreman K, Forouzanfar MH, Fowkes FGR, Franklin R, Fransen M, Freeman MK, Gabbe BJ, Gabriel SE, Gakidou E, Ganatra HA, Garcia B, Gaspari F, Gillum RF, Gmel G, Gosselin R, Grainger R, Groeger J, Guillemin F, Gunnell D, Gupta R, Haagsma J, Hagan H, Halasa YA, Hall W, Haring D, Haro JM, Harrison JE, Havmoeller R, Hay RJ, Higashi H, Hill C, Hoen B, Hoffman H, Hotez PJ, Hoy D, Huang JJ, Ibeanusi SE, Jacobsen KH, James SL, Jarvis D, Jasrasaria R, Jayaraman S, Johns N, Jonas JB, Karthikeyan G, Kassebaum N, Kawakami N, Keren A, Khoo J-P, King CH, Knowlton LM, Kobusingye O, Koranteng A, Krishnamurthi R, Lalloo R, Laslett LL, Lathlean T, Leasher JL, Lee YY, Leigh J, Lim SS, Limb E, Lin JK, Lipnick M, Lipshultz SE, Liu W, Loane M, Ohno SL, Lyons R, Ma J, Mabweijano J, Maclntyre MF, Malekzadeh R, Mallinger L, Manivannan S, Marcenes W, March L, Margolis DJ, Marks GB, Marks R, Matsumori A, Matzopoulos R, Mayosi BM, McAnulty JH, McDermott MM, McGill N, McGrath J, Medina-Mora ME, Meltzer M, Memish ZA, Mensah GA, Merriman TR, Meyer A-C, Miglioli V, Miller M, Miller TR, Mitchell PB, Mocumbi AO, Moffitt TE, Mokdad AA, Monasta L, Montico M, Moradi-Lakeh M, Moran A, Morawska L, Mori R, Murdoch ME, Mwaniki MK, Naidoo K, Nair MN, Naldi L, Narayan KMV, Nelson PK, Nelson RG, Nevitt MC, Newton CR, Nolte S, Norman P, Norman R, O'Donnell M, O'Hanlon S, Olives C, Omer SB, Ortblad K, Osborne R, Ozgediz D, Page A, Pahari B, Pandian JD, Rivero AP, Patten SB, Pearce N, Padilla RP, Perez-Ruiz F, Perico N, Pesudovs K, Phillips D, Phillips MR, Pierce K, Pion S, Polanczyk GV, Polinder S, Pope lii CA, Popova S, Porrini E, Pourmalek F, Prince M, Pullan RL, Ramaiah KD, Ranganathan D, Razavi H, Regan M, Rehm JT, Rein DB, Remuzzi G, Richardson K, Rivara FP, Roberts T, Robinson C, De Leòn FR, Ronfani L, Room R, Rosenfeld LC, Rushton L, Sacco RL, Saha S, Sampson U, Sanchez-Riera L, Sanman E, Schwebel DC, Scott JG, Segui-Gomez M, Shahraz S, Shepard DS, Shin H, Shivakoti R, Silberberg D, Singh D, Singh GM, Singh JA, Singleton J, Sleet DA, Sliwa K, Smith E, Smith JL, Stapelberg NJC, Steer A, Steiner T, Stolk WA, Stovner L, Sudfeld C, Syed S, Tamburlini G, Tavakkoli M, Taylor HR, Taylor JA, Taylor WJ, Thomas B, Thomson WM, Thurston GD, Tleyjeh IM, Tonelli M, Towbin JA, Truelsen T, Tsilimbaris MK, Ubeda C, Undurraga EA, van der Werf MJ, van Os J, Vavilala MS, Venketasubramanian N, Wang M, Wang W, Watt K, Weatherall DJ, Weinstock MA, Weintraub R, Weisskopf MG, Weissman MM, White RA, Whiteford H, Wiersma ST, Wilkinson JD, Williams HC, Williams SRM, Witt E, Wolfe F, Woolf AD, Wulf S, Yeh P-H, Zaidi AKM, Zheng Z-J, Zonies D, Lopez AD, Murray CJL (2012) Years lived with disability (YLDs) for 1160 sequelae of 289 diseases and injuries 1990-2010: a systematic analysis for the Global Burden of Disease Study 2010. Lancet 380:2163-2196. doi:10.1016/S0140-6736(12)61729-2

Witten IH, Frank E, Hall MA (2011) Data mining: practical machine learning tools and techniques. Morgan Kaufmann, San Francisco

Worachartcheewan A, Prachayasittikul S, Pingaew R, Nantasenamat C, Tantimongcolwat T, Prachayasittikul SR, Prachayasittikul V (2012) Antioxidant, cytotoxicity, and QSAR study of 1-Adamantylthio derivatives of 3-picoline and phenylpyridines. Med Chem Res 21:3514-3522. doi:10.1007/s00044-011-9903-y

Worachartcheewan A, Nantasenamat C, Isarankura-Na-Ayudhya C, Prachayasittikul V (2013) Predicting antimicrobial activities of benzimidazole derivatives. Med Chem Res 22:5418-5430. doi:10.3390/ijms10041670

Worachartcheewan A, Mandi P, Prachayasittikul V, Toropova AP, Toropov AA, Nantasenamat C (2014a) Large-scale QSAR study of aromatase inhibitors using SMILES-based descriptors. Chemometr Intell Lab Syst 138:120-126. doi:10.1016/j.chemolab.2014.07.017

Worachartcheewan A, Nantasenamat C, Isarankura-Na-Ayudhya C, Prachayasittikul V (2014b) Probing the origins of anticancer activity of chrysin derivatives. Med Chem Res. doi:10.1007/s00044-014-1260-1

Worachartcheewan A, Nantasenamat C, Owasirikul W, Monnor T, Naruepantawart O, Janyapaisarn S, Prachayasittikul S, Prachayasittikul V (2014c) Insights into antioxidant activity of 1-adamantylthiopyridine analogs using multiple linear regression. Eur J Med Chem 73:258-264. doi:10.1016/j.ejmech.2013.11.038

World Health Organization (2008) The Global Burden of Disease; 2004 Update. http://www.who.int/healthinfo/global_ burden_disease/2004_report_update/en/. Accessed 4 Aug 2015

\section{Submit your manuscript to a SpringerOpen ${ }^{\circ}$ journal and benefit from:}

- Convenient online submission

- Rigorous peer review

- Immediate publication on acceptance

- Open access: articles freely available online

- High visibility within the field

- Retaining the copyright to your article

Submit your next manuscript at $\boldsymbol{\nabla}$ springeropen.com 